OPEN ACCESS

Edited by:

Mark J. Post

Maastricht University, Netherlands

Reviewed by:

Sara M. Oliveira,

Laboratório Ibérico Internacional de

Nanotecnologia (INL), Portugal

Lorenzo Moroni,

Maastricht University, Netherlands

*Correspondence:

Shulamit Levenberg

shulamit@bm.technion.ac.il

Specialty section:

This article was submitted to

Sustainable Food Processing,

a section of the journal

Frontiers in Sustainable Food Systems

Received: 06 November 2018

Accepted: 29 May 2019

Published: 18 June 2019

Citation:

Ben-Arye T and Levenberg S (2019)

Tissue Engineering for Clean Meat

Production.

Front. Sustain. Food Syst. 3:46. doi: 10.3389/fsufs. 2019.00046

\section{Tissue Engineering for Clean Meat Production}

\author{
Tom Ben-Arye ${ }^{1,2}$ and Shulamit Levenberg ${ }^{1,2 *}$ \\ ${ }^{1}$ Department of Biomedical Engineering, Technion-Israel Institute of Technology, Haifa, Israel, ${ }^{2}$ Russell Berrie \\ Nanotechnology Institute, Technion-Israel Institute of Technology, Haifa, Israel
}

Increasing public awareness of foodborne illnesses, factory farming, and the ecological footprint of the meat industry, has generated the need for animal-free meat alternatives. In the last decade, scientists have begun to leverage the knowledge and tools accumulated in the fields of stem cells and tissue engineering toward the development of cell-based meat (i.e., clean meat). In tissue engineering, the physical and biochemical features of the native tissue can be mimicked; cells and biomaterials are integrated under suitable culture conditions to form mature tissues. More specifically, in skeletal muscle tissue engineering, a plurality of cell types can be co-cultured on a 3D scaffold to generate muscle fibers, blood vessels and a dense extracellular matrix (ECM). This review focuses on tissue engineering of skeletal muscle and the adjustments needed for clean meat development. We discuss the skeletal muscle structure and composition, and elaborate on cell types from farm animals that have the potential to recapitulate the muscle ECM, blood vessels, muscle fibers and fat deposits. We also review relevant biomaterials, primarily for fabricating scaffolds that can mimic the intramuscular connective tissues, as well as gene expression studies on the biological pathways that influence meat quality.

Keywords: tissue engineering, skeletal muscle, clean meat, cell-based meat, cultured meat, cellular agriculture, cell culture

\section{INTRODUCTION}

\section{Why Clean Meat?}

Clean meat, meat produced from cells cultures, is a prominent alternative for traditional meat, derived from live animals (Post, 2012; Slade, 2018). This approach gained increasing attention in public opinion, popular media, animal welfare organizations, the scientific community, and among investors (Goodwin and Shoulders, 2013; Schneider, 2013; Verbeke et al., 2015; Stephens et al., 2018b), particularly after the production of the first clean meat prototype (Post, 2014). Animal-based food products are considered inefficient, as animals consume large amounts of food throughout their lives, of which up to $97 \%$ of the calories are lost for processes regarding body maintenance and the production of non-edible tissues (Schmidinger, 2012; Flachowsky et al., 2018; Gaydhane et al., 2018; Sarlio, 2018). When compared to other industries, animal-based products have a larger environmental footprint compared to plant-based products in terms of soil and water demand, and greenhouse gas (GHG) emission, with the beef industry imparting the heaviest environmental impact (Peters et al., 2007; Tuomisto and de Mattos, 2011; Eshel et al., 2014; Scarborough et al., 2014). According to the report of the Food and Agriculture Organization of the United Nations, the livestock sector is responsible for $14.5 \%$ of GHG emissions, and taps $30 \%$ of Earth's terrain and $8 \%$ of the global freshwater (Steinfeld et al., 2006; Gerber et al., 2013). With an expected doubling of the global demand for meat by 2050, traditional meat production systems cannot be considered sustainable. 
Intensive factory farming and poor animal welfare conditions are common causes of foodborne illnesses such as swine and avian influenza (Greger, 2007). They also contribute to the spreading of E.coli, salmonella and campylobacter, which can be found in meat (Anomaly, 2015). Producing meat in a sterile and controlled environment could prevent these problems and improve food safety. In addition, $70-80 \%$ of the antibiotics used in the United States are given to farm animals (Kümmerer, 2003; Elliott, 2015). Overuse of antibiotics induces selection of antimicrobial resistant (AMR) strains, a major human health concern (Avesar et al., 2017; Chen et al., 2017; Tang et al., 2017). Colistin AMR originated in 2015 in pig farms (Reardon, 2017) and was later found in chicken and pig in Vietnam and South America (Nguyen et al., 2016; Monte et al., 2017). It is estimated that by 2050, AMR will be responsible for more deaths than cancer (O’Neill, 2014) and to cost \$2.9 trillion annually to the OECD countries (Friedman et al., 2016). Although the magnitude of antibiotics use in clean meat production still requires investigation, it has the potential to be lower than the current use in the meat industry due to the sterile culture conditions and the possible use of antibiotic-free media (Specht et al., 2018).

Ethical concerns regarding factory farms (Verbeke and Viaene, 2000; Schröder and McEachern, 2004; Herzog, 2016) and the slaughter of animals is another drive behind clean meat research (Hopkins and Dacey, 2008; van der Weele and Driessen, 2013; Sharma et al., 2015). The public and the scientific community have come to respect farm animals as sentient beings, with physical and psychological needs (Hughes, 1995; Dawkins, 2006; Duncan, 2006; Webster, 2006; Panskeep and Others, 2012). The cost of raising a chicken humanely (Broom, 1991; Broom and Fraser, 2015), similar to that of a pet (Council, 2010), is 23 orders of magnitude higher than the cost of products made from that animal (United States Department of Agriculture, 2018). In other words, animal-based meat must compromise on animal interests, due to economic constraints (Webster, 2001; Lusk and Norwood, 2011). Since the overwhelming majority of domesticated animals are raised for meat, pushing for the obsoletism of animal-based meat is essential from an altruistic stance (Green, 2008; Elder and Fischer, 2017; Broad, 2018).

From a culinary perspective, fine-tuning of meat components is difficult in live animals, and is achieved by selecting specific breeds and following complex feeding protocols (Smith et al., 2009). In clean meat, cells are cultured in-vitro in a customizable and controlled platform. The simple and precise manipulation of the cell microenvironment could be used to fine-tune meat

\footnotetext{
Abbreviations: AMR, Antimicrobial resistance; BAM, Bio-artificial muscle; BSC, Bovine satellite cells; C/EBP, CCAAT/enhancer-binding protein; EC, Endothelial cells; ECM, Extracellular matrix; ESC, Embryonic stem cells; FABP4, Fatty acid binding protein 4; FAP, Fibro/adipogenic precursors; FAS, Fatty acid synthase; FGF, Fibroblast growth factor; G3P, Glycerol-3-phosphate; GAG, Glycosaminoglycans; GF, Growth factor; GHG, Greenhouse gas; HA, Hyaluronic acid; hb-EGF, Heparin-binding EGF-like growth factor; IGF-1, Insulin-like growth factor 1; IMF, Intramuscular fat; iPSC, Induced pluripotent stem cells; LCFA, Long-chain fatty acids; LIF, Leukemia inhibitory factor; MSC, Mesenchymal stem cells; PEG, Polyethylene glycol; PG, Proteoglycan; PLGA, Poly(lactic-co-glycolic acid); PLLA, Polylactic acid; PPARG, Peroxisome proliferator-activated receptor $\gamma$; SC, Satellite cells; SVC, Stromal vascular cells; TGF- $\beta$, Transforming growth factor beta.
}

traits. In addition, combinations of cells from different species may give rise to new and unprecedented flavors. This simple, fast and intuitive meat manipulation platform can facilitate a new $\mathrm{R} \& \mathrm{D}$ field of customizable meat products.

\section{A New Objective}

An engineered tissue is traditionally optimized for biological functionality, improved post-transplantation viability, biodegradability and negligible immune response (Lanza et al., 2011). To reach these goals, quantifiable protocols are developed, and a rigorous series of experiments are performed to assess the effect of specific factors on the overall quality of the tissue. Optimally, experiments are conducted using factorial designs, in which both main factors and their interactions are measured (Chen et al., 2011). A similar approach is required for clean meat optimization, with focus on flavor (taste and aroma), texture, cost, nutritional value and food safety (Miller et al., 2001; Edelman et al., 2005; Post and van der Weele, 2014; Listrat et al., 2016; Gasteratos and Sherman, 2018).

Flavor assessments are a key challenge in clean meat research. Meat contains thousands of flavor molecules (Pearson and Dutson, 1994; Shahidi, 2012), including amino acids, hemoproteins (Nollet, 2012), sulfur and carbonyl compounds (Calkins and Hodgen, 2007), lipids (Shahidi, 2002; Wood et al., 2004), short peptides (Claeys et al., 2004), and additional flavor volatiles (Shahidi et al., 1986; Gorraiz et al., 2002). An additional hurdle stems from the small size of lab samples; standard protocols used to analyze meat quality are designed to test samples ranging from whole animals (Mitchell, 2007) to tens of grams (Anderson, 2007), which are at least three orders of magnitude larger than experimental lab samples. Light diffraction is a fast, inexpensive and non-invasive meat analysis method (Prieto et al., 2009; Damez and Clerjon, 2013). This technology is based on a reference database of light diffraction patterns from meat samples with known composition. The correlation between a measured sample and the reference database is used to estimate the sample's composition with high accuracy. Scaling down this technology is feasible (Jordan et al., 2009) and could accelerate clean meat research. However, light diffraction only provides an estimate of main components, such as fat and collagen content in the sample. Molecular profiling of lab samples can be obtained by chromatographic separation, followed by mass spectrometry identification and quantification (Shahidi, 2012; Trivedi et al., 2016). A reference database of molecular profiles obtained from meat samples could be beneficial to interpret and standardize experimental results (D’Alessandro et al., 2012; Trivedi et al., 2016; Gilbert-López et al., 2017). While molecular profiling may be slower and more expensive, it provides quantification of flavor molecules, and is more suited for developing novel tissues, which composition may often be outside the scope of the reference database.

Texture measurements are simpler, and can easily predict sensory attributes (Luckett et al., 2014). They can be performed using existing devices (Kramer and Szczesniak, 1973; Pearson and Dutson, 1994), but may require adaptation of current protocols or instruments to assess smaller samples in broader suboptimal ranges. Factors that can influence clean meat texture 
include muscle fiber maturation (Koohmaraie et al., 2002) and alignment, extracellular matrix (ECM) protein content and alignment, intramuscular fat (IMF) content (Kramer and Szczesniak, 1973), and scaffold material and structure. Static strain can be used to increase myotube and ECM alignment with the added value of improved muscle maturation (De Deyne, 2000; Edelman et al., 2005; Post, 2012; Heher et al., 2015); however, the scalability of the process may be difficult. Scalable alignment can be induced via scaffold design, by generating aligned fibrous scaffolds or by micropatterning (Choi et al., 2008; Aviss et al., 2010; Rodriguez and Larkin, 2018).

Cost is probably the key hurdle, as clean meat borrows tools from the expensive and heavily regulated field of regenerative medicine, and applies them in the food industry, which has one of the lowest margins of profit. The main expenditures of clean meat production are biomaterials and their purity assurance, human resources, facilities and measurement tools. Specht (2019) estimates that $55-95 \%$ of the production cost could be attributed to media use, and that $99 \%$ of the media cost can be attributed to Growth factors. Her review discusses different scenarios for cost reduction. While growth factors (GFs) are costly biomaterials, due to protein purification (Van der Gucht, 2018), their contribution to tissue engineering is invaluable. Replacing purified GFs with GF-producing cells is possible, however may complicate the regulation of GF concentration, as experimental parameters can influence GF expression levels in these cells. Two alternative approaches are to produce these molecule at a lower grade of purification (or without purification), or to generate inexpensive analogs of these molecules. Customized bioreactors need to be developed and optimized for clean meat production, to improve the efficiency of media use, and recycle main media components (Moritz et al., 2015; Specht et al., 2018; Stephens et al., 2018a).

\section{CELLS}

Meat, or skeletal muscle, contains about $90 \%$ muscle fibers, $10 \%$ connective and fat tissues (Listrat et al., 2016) and 0.3\% blood (Warriss and Rhodes, 1977; Nollet, 2012). Skeletal muscle tissues, aimed for tissue regeneration, can be generated in $3 \mathrm{D}$ scaffolds by co-culturing muscle cells, endothelial cells (ECs) and ECMproducing supporting cells (Figure 1) (Edelman et al., 2005; Levenberg et al., 2005; Shandalov et al., 2014; Gholobova et al., 2015; Egozi et al., 2016), but lack fat and blood components. In order to recapitulate the fat composition of the native skeletal muscle tissue, IMF should be generated from adipocytes. As for blood components, with the exception of fish, the majority of the hemoproteins in meat stem from myoglobin (on average $1.5 \%$ of the protein content of meat) found inside muscle fibers (Listrat et al., 2016). This means that the production of "clean blood" might be of low concern, especially since blood cultures are not established yet for medical purposes. Neural cells also play a crucial regulatory role in the skeletal muscle, providing electrical signals that influence tissue homeostasis and maturation (Langelaan et al., 2011; Post and Hocquette, 2017). While innervation may be difficult to attain in a scalable and cost-effective manner, electrical signals may mimic some of the neural cells essential roles (Langelaan et al., 2010). While current methods are considered wasteful for clean meat production, it may be advantageous to explore more energy efficient means of artificial electrical stimulations. As for the cell source, the following sections will emphasize the use of bovine cells, as developing clean beef could be considered as a pragmatic approach for the initial stages of clean meat production, since (1) the overwhelming majority of tissue engineering research is done in mammalian cells, (2) beef is considered an expensive meat, (3) beef has a larger ecological impact compared to other conventional meats (Tuomisto and de Mattos, 2011), and (4) biopsies from larger animals are less invasive. Biomarkers of major cell types found in bovine muscle have been previously summarized (Du et al., 2015; Guo et al., 2015). Additional cell types found in the muscle, their roles and biomarkers were summarized by Tedesco et al. (2017).

\section{Stem Cells}

Stem cells are a population of progenitor cells, which can proliferate to increase the cell population, and differentiate to develop a specialized functionality. Stem cell research is an established niche in animal science, focused on myogenic and adipogenic stem cells, crucial for clean meat research (Dodson et al., 2015). A recent report described a first stable culture of bovine embryonic stem cells (ESC) (Bogliotti et al., 2018; Yuan, 2018), which could potentially differentiate into all cell types required to recapitulate skeletal muscle development (Du et al., 2010a; Thorsteinsdóttir et al., 2011; Yan et al., 2013; Chal and Pourquié, 2017), and form a cell bank with an unaltered and stable karyotype, eliminating further dependence on animals for cell isolation. Mesenchymal stem cells (MSC) are another promising candidate, due to their abundance and roles during muscle development (Du et al., 2010b), and their ability to differentiate into myocytes, adipocytes, fibroblasts and ECs (Oswald et al., 2004; Bosnakovski et al., 2005; Huang et al., 2012; Yan et al., 2013; Jana et al., 2016; Ramírez-Espinosa et al., 2016; Okamura et al., 2018). During muscle development, the majority of MSCs commit to the myogenic lineage, generating muscle fibers and a pool of satellite cells. Other MSCs commit to the fibro/adipogenic lineages, generating a pool of fibro/adipogenic progenitor cells (FAPs) (Du et al., 2013). MSCs undergo senescence in-vitro (Bonab et al., 2006; Wagner et al., 2008), however, under appropriate culture conditions, certain MSC subtypes can expand and maintain their differentiation potential (King and Miller, 2007; Nekanti et al., 2010; Cardoso et al., 2012; Gottipamula et al., 2016). Induced pluripotent stem cells (iPSC) can also be considered as a cell source for clean meat production. iPSC are simple to produce and are extensively studied, making them valuable for lowering the cost and research needed to develop stable stem cell lines. They also simplify the cell isolation, allowing to harvest ubiquitous matured cell types (Keeney et al., 2012). However, they require gene editing, suffer from low yields, and may not precisely mimic the behavior primary stem cells (Roberts et al., 2015; Specht et al., 2018). As such, it is possible they would complicate clean meat regulatory procedure and consumer acceptance. 


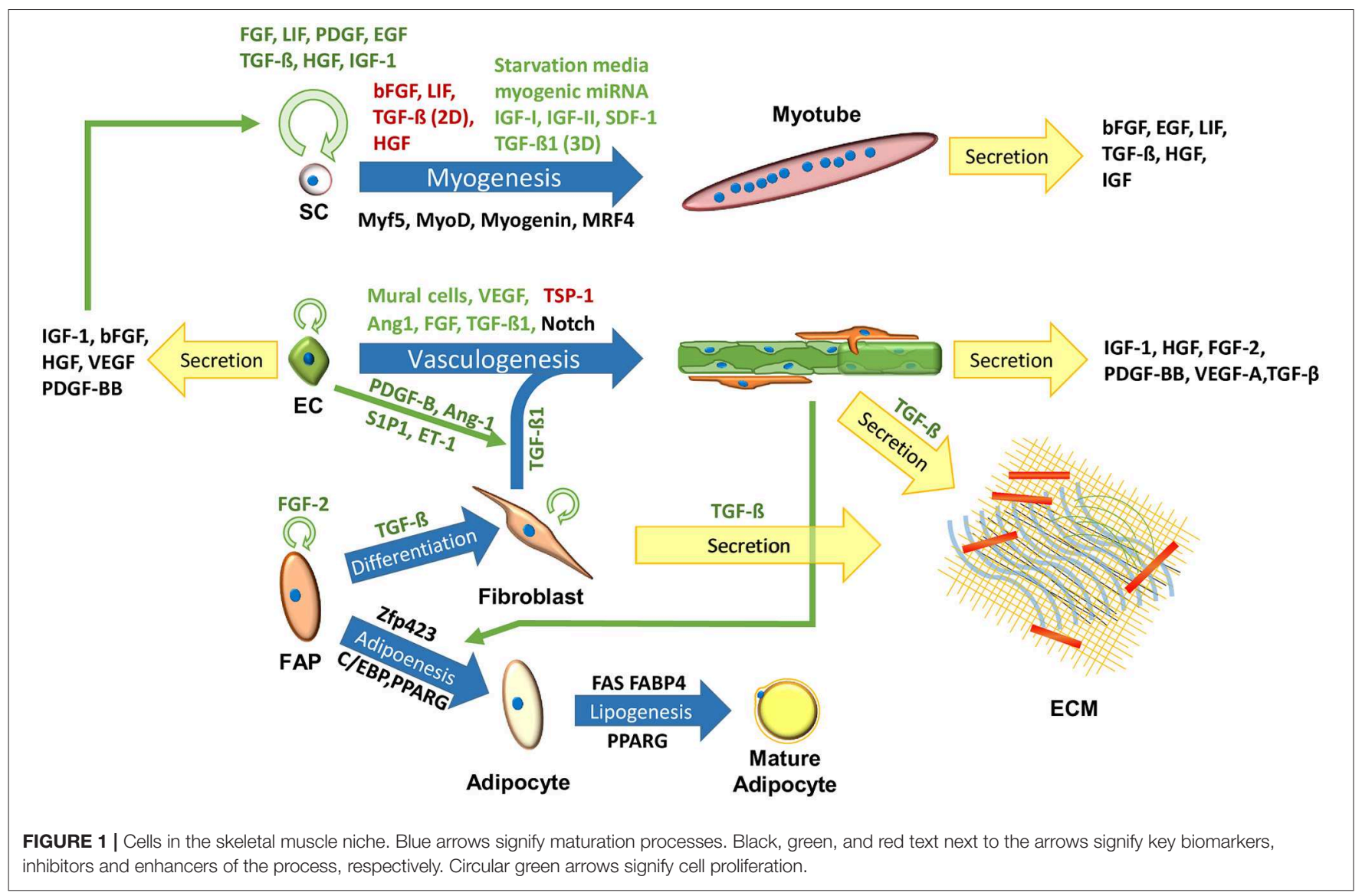

\section{Satellite Cells and Myogenesis}

Satellite cells (SCs) are adult stem cells, which can be found in skeletal muscle tissues, and take part in muscle repair (Péault et al., 2007; Cosgrove et al., 2009; Yin et al., 2013). Methods for working with SCs extracted from different species have been summarized by Burton et al. (2000). The paper provides a table of references sorted by species, and a comparison of SC characteristics, response to GFs, and isolation, growth, and differentiation protocols. Bovine satellite cells (BSCs) were used to create the first clean meat prototype (Post, 2014), and their growth in bioreactors for clean meat production was recently assessed (Verbruggen et al., 2018). BSCs can be isolated from bovine carcasses (Dodson et al., 1987; Frey et al., 1995; Muroya et al., 2001; Kamanga-Sollo et al., 2004, 2008; Ding et al., 2018), biopsies (Frey et al., 1995) or fetuses (Bridge et al., 1998; Will et al., 2015). The muscle tissue is ground and enzymatically digested using pronase, collagenase II or trypsin. The BSC fraction is then enriched by a preplating method and can be further purified by FACS of cells positive for CD56 and CD29, and negative for CD45 and CD31 (Ding et al., 2018).

$\mathrm{SC}$ proliferation and myogenesis can be regulated by the judicious use of GFs (Figure 1). Addition of LIF (Vitello et al., 2004; Nicola and Babon, 2015), TGF- $\beta$ (Vitello et al., 2004; Kollias and McDermott, 2008) and FGF (Allen and Boxhorn, 1989; Pawlikowski et al., 2017) to the BSC media in 2D cultures, has been shown to inhibit spontaneous differentiation, crucial for optimal cell expansion. Addition of LIF (Austin and Burgess, 1991; Nicola and Babon, 2015), heparin-binding epidermal growth factor (hb-EGF) (Thornton et al., 2015), TGF$\beta$ (Vitello et al., 2004) and insulin-like growth factor 1 (IGF1) (Allen and Boxhorn, 1989; Vitello et al., 2004) can improve BSC proliferation. In addition to its central role in muscle development, TGF- $\beta$ contributes to mature skeletal muscle mass, and is a key regulator of intramuscular fibrogenesis (Kollias and McDermott, 2008; Miao et al., 2016). In addition, it was shown that TGF- $\beta 1$ suppressed myogenesis in $2 \mathrm{D}$ cultures, while enhancing myogenesis in $3 \mathrm{D}$ cultures, rendering it a valuable regulator of in-vitro muscle tissue development (Krieger et al., 2018). Myogenesis can be induced by substrate stiffness (LevyMishali et al., 2009; Syverud et al., 2014), IGFs and myogenic miRNA (Vitello et al., 2004; Yin et al., 2013), or by inhibition of anti-myogenic GFs produced by nearby cells (Christov et al., 2007; Yin et al., 2013). Inexpensive analogs for key GFs, or of additional molecules that can influence their metabolic pathways [e.g., myogenic miRNA (Ge et al., 2011)], may benefit clean meat research (Ding et al., 2018).

A detailed list of SC biomarkers, including the lineage markers, Pax7 and Myf5, was summarized by Yin et al. (2013). These and additional biomarkers can be used to track SC differentiation into myotubes (Zammit et al., 2006). The 
predominant test to quantify SC differentiation is the fusion index (FI), which is defined as the percentage of nuclei inside the myotubes from the total number of nuclei in the sample. FI can be determined by assessing (1) myotube-specific nuclear staining (myogenin), (2) colocalization of non-specific nuclear staining (e.g., DAPI) and antibodies that stain proteins abundant in myotubes (e.g., MYH and desmin), or (3) inexpensive colorimetric stainings (Veliça and Bunce, 2011). Methods 1 and 2 can also be used to quantify $3 \mathrm{D}$ samples, and method 2 also be used to visualize myotube morphology. It should be noted that the main role of BSCs is in muscle repair, and that they are formed in later stages of muscle development (Du et al., 2015). BSCs also undergo senescence in-vitro, which might be minimized by recapitulating the SC niche (Boonen et al., 2009; Cosgrove et al., 2009; Yin et al., 2013; Roberts et al., 2015; Jana et al., 2016; Cai et al., 2017; Ding et al., 2018).

\section{Fibroblasts and ECM}

The ECM, i.e., the acellular part of the tissue that surrounds the cells, is a key component of all tissues. The skeletal muscle ECM is responsible for tissue elasticity, generates adhesion points for cell adherence, provides cells with a 3D environment and regulates cell proliferation, differentiation, migration, morphology and alignment via biochemical and biophysical cues (Tse and Engler, 2011; Hausman, 2012; Chaturvedi et al., 2015; Fuoco et al., 2016; Grzelkowska-Kowalczyk, 2016). The ECM composition and roles are not constant, but change during the muscle development in a process called fibrogenesis, in parallel to myogenesis and adipogenesis (Thorsteinsdóttir et al., 2011; Yan et al., 2013; Miao et al., 2016). In addition to its biological roles, the ECM contains nutrients such as proteins (mostly collagens), and glycosaminoglycans [mostly hyaluronic acid (HA)], and affects the tissue texture and the overall quality of the meat (Purslow, 2005; Guo et al., 2015; Duffy et al., 2016; Listrat et al., 2016; Huang et al., 2017).

The ECM is mainly composed of collagen fibers and proteoglycan (PG) matrix, but also includes glycosaminoglycans (GAGs) and fibrous proteins such as elastin, fibronectin, and laminin (Thorsteinsdóttir et al., 2011; Listrat et al., 2016). The muscle ECM has three ascending layers of connective tissues, in term of size and wall thickness (Figure 2): the endomysium that fills the gaps between the muscle fibers, the perimysium (Passerieux et al., 2006) that compartmentalize bundles of muscle fibers (fascicles), and the epimysium that envelops the entire muscle (Purslow, 2010; Brazile et al., 2017). The perimysium varies in size and can be divided into primary and secondary perimysium. The primary perimysial layers are smaller, contain fewer muscle fibers and have thinner walls compared to the secondary perimysium (54.6-133 $\mu \mathrm{m}$ wall thickness in bovine) (Purslow, 2010). While all layers are mainly composed of collagens I and III, their relative ratios differ, and other collagen types can be found interspersed. Collagen IV is an essential component of the basement membrane and plays a role in cell-matrix interactions and SC niche (Gillies and Lieber, 2011; Cai et al., 2017). Age-related changes include an increase in collagen concentration, and changes in collagen type distribution and crosslinking (Kragstrup et al., 2011). A thorough review of the different species of collagens, their biological role and tissue distribution was published by Kadler et al. (2007). To a certain extent, mimicking the epimysium, perimysium and endomysium morphology and mechanical properties can be achieved by careful scaffold design. The basement membrane may be difficult to recapitulate prior to cell seeding, as it is tailored to the myotube structure.

Although most cell types contribute to ECM development (Guo et al., 2015), a supporting cell type whose main role is to secrete ECM, is essential. The majority of skeletal muscle tissue ECM is deposited and remodeled by fibroblasts (Figure 1) (Kjaer, 2004; Gillies and Lieber, 2011; Mackey et al., 2017). Fibroblast and myofibroblasts (Baum and Duffy, 2011) are simple to isolate and grow, and have a short cell cycle. They were shown to promote vascularization and muscle development in tissue engineered constructs (Shandalov et al., 2014; Ciccone, 2015; Mackey et al., 2017; Krieger et al., 2018), and are considered to have an important role in clean meat production (Pandurangan and Kim, 2015). However, isolated fibroblasts are usually not very well defined, and are often comprised of several subpopulations with few specific markers (Chapman et al., 2016). In addition, although fibroblast short cell cycle may be beneficial for scale-up processes, it may be unfavorable for co-culture, as their relative concentration is difficult to control. Alternatively, it is possible to produce the ECM separately, lyophilize it into a powder (Gilbert et al., 2005), which can then be used to generate scaffolds or hydrogels for cell seeding. However, such reconstituted ECMs will be homogenous, which may fail to fill the functional, geometrical and compartmental roles of the ECM (Gillies and Lieber, 2011; Huang et al., 2017).

\section{ECs and Vascularization}

Muscle tissues are rich in microvascular networks (Figure 2) (Jain et al., 2005; Guo et al., 2015). These networks are not only essential to surpass diffusion limitation (Griffith et al., 2005), which may be improved in-vitro using perfusion bioreactors (Rouwkema and Khademhosseini, 2016), but are also associated with the SC niche (Christov et al., 2007) and regulate skeletal muscle tissue regeneration and maturation through angiocrine signaling (Figure 1) (Christov et al., 2007; Butler et al., 2010; Koffler et al., 2011; Rafii et al., 2016). Microvascular networks also play a key role in generating the conditions required for adipogenesis (Varzaneh et al., 1994; Cao, 2007, 2013; Du et al., 2015), and impact the maturation of nearby ECM-secreting cells (Ciccone, 2015; Landau et al., 2018), which further regulate muscle regeneration (Forbes and Rosenthal, 2014). ECs can form these networks under appropriate culture conditions (Lovett et al., 2009), such as co-culture with mural cells (Sims, 1986; Allt and Lawrenson, 2001; Bergers and Song, 2005; von Tell et al., 2006; Rouwkema et al., 2008), fibroblasts (Levenberg et al., 2005; Kunz-Schughart et al., 2006) or MSCs (Landau et al., 2017; Perry et al., 2017b; Freiman et al., 2018). Guo et al. (2015) provide evidence of the role of bovine muscle ECs in ECM synthesis and remodeling, and discuss their regulatory effect on myoblasts, SCs and fibro/adipogenic precursors (FAPs). Recent studies showed that bovine stromal vascular cells (SVC) can be used to promote both angiogenesis and adipogenesis in-vitro 


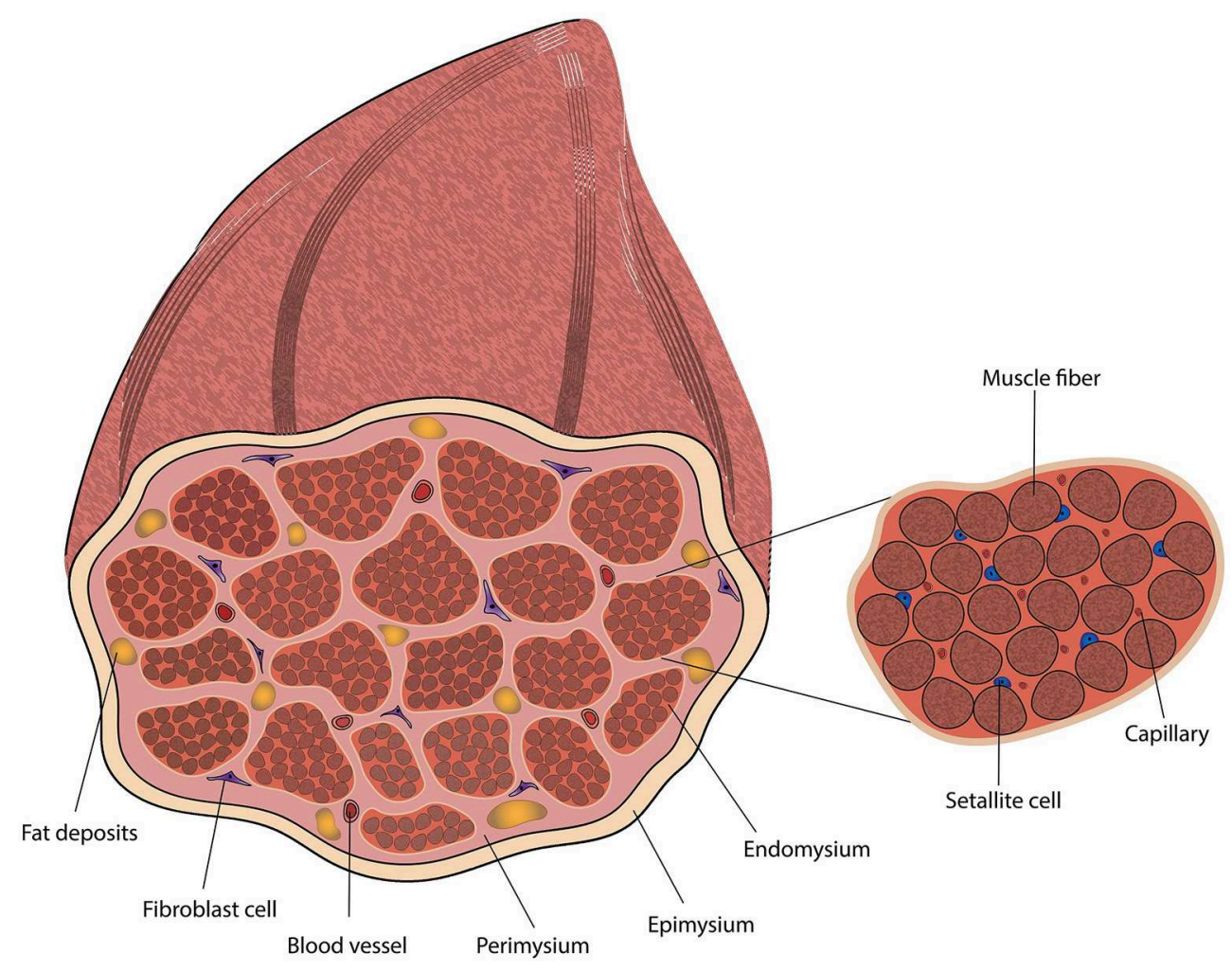

FIGURE 2 | Diagram of skeletal muscle tissue, including a magnification of a muscle fascicle.

(Ma et al., 2018), which can be explained by the heterogeneity of the SVC (Wittmann et al., 2015), meaning cell sorting is essential for scale-up. While the most characterized bovine ECs are the bovine aortic endothelial cells (Jaffe, 2012), their biological role may not be optimal for muscle regeneration. Bovine skeletal muscle microvascular endothelial cells are commercially available, and were shown to generate vascular networks in 3D constructs in-vitro with lumen-like structures (Yang et al., 2001). While vascularization has an important role in tissue development, cultured meat of lower cell plurality may be simpler to produce without them, as blood vessels may not be an essential component of meat taste or texture.

\section{Adipocytes and IMF}

IMF accounts for about $80 \%$ of the muscle fat, while the other $20 \%$ is found inside myofibers; its amount and fatty acid composition have a crucial role in meat quality, affecting meat juiciness, flavor, tenderness and nutritional value (Wood et al., 2008; Hocquette et al., 2010; Hudson et al., 2015). IMF is created via adipogenesis, in which stem cells differentiate into adipocytes, and lipogenesis, in which triglycerides are accumulated inside the adipocytes (Figure 1). Adipogenesis commences with MSCs or fibrogenic/adipogenic progenitor (FAP) cells commitment to the adipogenic lineage, which is regulated by Zfp423 (Huang et al., 2012). The resulting preadipocytes can further differentiate into adipocytes in a process regulated by transcription factors from the CCAAT/enhancer-binding protein (C/EBP) family, and by the receptor they induce, i.e., peroxisome proliferatoractivated receptor gamma (PPARG) (Huang et al., 2012; Du et al., 2015). Adipogenesis can be induced using a cocktail of adipogenic-inducing agents, anti-diabetic drugs (Troglitazone and Rosiglitazone), or commercial adipogenic differentiation kits (Grant et al., 2008; Lengi and Corl, 2010; Cardoso et al., 2012; Huang et al., 2012; Ma et al., 2018). However, the use of such chemicals may render the tissue unsuitable for consumption. Mehta et al. (2019) provides a detail protocol for bovine adipogenesis aimed for clean meat production. This publication includes a detail isolation and culture protocol of the SVC, and an efficient fatty acid-mediated protocols for adipogenesis in 2D plates and 3D alginate-based scaffolds. SC and fibroblast differentiation into adipocytes was also demonstrated in-vitro (Hocquette et al., 2010). In the lipogenesis metabolic pathway, triglycerides are synthesized from longchain fatty acids (LCFAs) and glycerol-3-phosphate (G3P) (Hocquette et al., 2010). Functional proteins, such as fatty acid synthase (FAS), fatty acid binding protein 4 (FABP4) and PPARG, promote adipocyte maturation and may be used as lipogenesis markers (Moseti et al., 2016). Simple protocols for tracking adipogenesis and lipogenesis include, quantitative colorimetric oil red O staining (Kraus et al., 2016), fluorometric Nile red staining, FABP4 immunolabeling (Eom et al., 2018), qPCR of PPARG and FABP4, flow cytometry, or one of many commercially available adipogenesis assay kits (Aldridge et al., 2013). 
Generating IMF in-vitro may require intensive research, as current adipose tissue engineering research focuses on fat outside the muscle (Hong et al., 2005; Gomillion and Burg, 2006; Brett et al., 2017) and uses human and mouse models, which protocols are inefficient for ruminant animals (Laliotis et al., 2010; Ma et al., 2018). Research on adipose tissue vascularization using matured ECs and MSCs, revealed a synergetic effect between angiogenesis and adipogenesis (Kang et al., 2009; Wittmann et al., 2015; Volz et al., 2016). The edible HA, a major component of the ECM (Qazi et al., 2015), has been used to generate scaffolds that induced adipogenesis in-vitro (Halbleib et al., 2003). Hausman (2012) discussed the effect of the ECM on adipogenesis in farm animals, suggesting that laminin, collagen $\mathrm{V}$ and $\mathrm{VI}$ are key ECM components in intramuscular adipogenesis.

Research on IMF is extensive in farm animals, such as bovine (Harper and Pethick, 2004; Takenouchi et al., 2004; Taniguchi et al., 2008; Du et al., 2010b; Romao et al., 2011; Cardoso et al., 2012; Huang et al., 2012; Hudson et al., 2015; Guan et al., 2017; Ma et al., 2018), porcine (Hausman and Poulos, 2004; Zhang et al., 2014; Chen et al., 2018; Won et al., 2018), sheep (Dodson et al., 1997; Tong et al., 2008; Zhou et al., 2017; Pan et al., 2018) and chicken (Qiu et al., 2017; Wang et al., 2017a; Cui et al., 2018; Fu et al., 2018), and have brought to the development of a wealth of isolation, growth, characterization and differentiation protocols.

\section{BIOMATERIALS AND SCAFFOLDING}

Biopolymers, growth factors, enzymes, and numerous analytical molecules, are extensively used for cell culture and tissue engineering. For clean meat production, these molecules should be derived from inexpensive, animal-free sources. Transgenic plants can be used for cost-effective (Xu et al., 2016), mass production of biomaterials such as collagen (Shoseyov et al., 2013; Shoseyov and Stein, 2017), elastin (Conley et al., 2009), trypsin (Woodard et al., 2003), growth factors and antibodies (Sack et al., 2015; Snell et al., 2015; Xu et al., 2016). Werkmeister and Ramshaw (2012) surveyed recombinant proteins used as tissue engineering scaffolds, including their source, cost and scalability. Wang et al. (2017b) discuss a range of platforms for recombinant collagen production and their challenges, including collagen I and III. The paper claims that current platforms are costly, and generate collagen without the correct post-translational modifications, limiting their biological functionality. However, the human collagen I produced in plants by the Shoseyov lab, proved sufficiently similar to native collagen by the author, and was flagged as an inexpensive, scalable production system. In addition, the paper argues that in-vitro cell-free synthesis might be an inexpensive, highly controlled platform for protein synthesis.

In order to promote tissue development, the plurality of cell types need to be co-cultured inside a $3 \mathrm{D}$ scaffold that mimics their natural environment. The scaffold can be composed of either a hydrogel, a macroporous, sponge-like biomaterial or their combination. While the macroporous biomaterial can provide the macrostructure and mechanical support, the hydrogel can provide cells an elastic 3D microenvironment. To some extent, scaffolds should recapitulate the different layers of the skeletal muscle connective tissue. The macroporous biomaterial should recapitulate the mechanical properties of the perimysium, the hardened connective tissue that surrounds the fascicles, while the hydrogel inside the pores should mimic the endomysium.

Polymers that degrade during the tissue culture period can be applied, however, disposal methods of the degraded molecule or their continued presence must be taken into account. The degradation kinetics of such polymers can be tuned using enzymes or by incorporating weak points inside the polymer structure (Keeney et al., 2012). Traditionally, scaffolds are designed to degrade into safe biomolecules which can be assimilated into the patient's metabolic pathways. For clean meat purposes, scaffolds should be composed of biopolymers designed to degrade into molecules with favorable organoleptic properties. This could be achieved by judicious polymer selection, monomer chemistry, and chemical modification of the scaffold. Shit and Shah (2014) provide a thorough list of edible polymers, including hydrocolloids, polypeptides, lipids, synthetic polymers and composite polymers. The paper discusses their molecular functionality, composition and mechanical properties, but does not elaborate on their possible applications in tissue engineering. Comprehensive reviews of the role of biomaterials in human skeletal muscle tissue engineering have been published, with emphasis on polymers used for scaffold fabrication (Keeney et al., 2012; Qazi et al., 2015). The concepts behind their fabrication and design, with the proper selection of flavor-enhancing biomaterials, can be used to generate novel hydrogels and scaffolds for clean meat purposes.

\section{Scaffolds}

Macroporous scaffolds are sponge-like, 3D biomaterials that define the dimensions of the tissue and provide it with mechanical support. These scaffolds constitute a large portion of the final product, which would be commonly defined as a hybrid cell-based meat. As such, the development of novel meatlike macroporous scaffolds, with consideration to their flavor, nutritional value and texture is required. For example, depending on their synthesis procedure, algae-based scaffolds may contain flavor molecules that could be beneficial for clean fish but undesirable for clean beef production (Sarkar and Choudhury, 2017; Grahl et al., 2018).

Macroporous scaffolds vary mainly in their architecture, which is governed by fabrication techniques (Loh and Choong, 2013), and in their molecular composition. They are often generated from edible materials, such as proteins, polysaccharides, native ECM and decellularized plants (Daamen et al., 2003; Loh and Choong, 2013; Courtenay et al., 2018; Hickey et al., 2018). Plant protein-based scaffolds are an appealing candidate for clean meat, due to their nutritional value, low cost and cytocompatibility (Reddy and Yang, 2011; Chien et al., 2013; Huang et al., 2018). Scaffold architecture 
can be defined by pore size distribution, porosity, and pore interconnectivity. Higher scaffold porosity can improve nutrient flow, ECM deposition, cell viability, cell adhesion and cell proliferation (Zeltinger et al., 2001). Rational combination of the scaffold architecture, composition, coating and filler hydrogel, gives rise to mechanical cues that regulate cell behavior. Scaffolds can be further arranged using anisotropic architecture, anisotropic materials or surface patterning, which can improve both scaffold texture and myotube alignment and maturation (Woerdeman et al., 2005; Beier et al., 2009; Qazi et al., 2015; Wolf et al., 2015; Jana et al., 2016; Cai et al., 2017; Oguz et al., 2018).

Specific cell types require different cell niches, and will thus better thrive on scaffolds bearing properties identical to their native niches (Zeltinger et al., 2001). While fibroblasts and myoblasts may be indifferent, to some extent, to the pore size, the optimal pore size for other cell types may vary with the experiment design, scaffold composition and cell source (Levy-Mishali et al., 2009; Loh and Choong, 2013). Engineered vascularized skeletal muscle tissues, comprised of muscle cells, fibroblasts and ECs were reported to develop inside PLLA-PLGA scaffolds with a pore size of 200-600 $\mu \mathrm{m}$ (Shandalov et al., 2015; Perry et al., 2017b). The optimal pore size for vascularization of monocultures on a porous PEG scaffold, was shown to be $160-270 \mu \mathrm{m}$ (Loh and Choong, 2013). Reports of pore size for adipogenesis include 6-70 $\mu \mathrm{m}$ for murine ESCs (Loh and Choong, 2013), 100-300 $\mu \mathrm{m}$ for rat MSCs (Neubauer et al., 2005), 135-633 $\mu \mathrm{m}$ for rat preadipocytes (Patrick et al., 1999), $400 \mu \mathrm{m}$ or $50-340 \mu \mathrm{m}$ for human preadipocytes (Von Heimburg et al., 2003; Hemmrich et al., 2005) and 200-400 $\mu \mathrm{m}$ for human MSCs (Hong et al., 2005). Further study on the effect of pore size on bovine intramuscular adipogenesis is still necessary.

The mechanical cues sensed by cells growing on a scaffold, are generated by complex interactions involving the macroporous biomaterial, the hydrogel or liquid inside the scaffold pores, and the cells themselves (Levy-Mishali et al., 2009; Purslow, 2010). While mimicking the elastic properties of fat tissues $(\sim 2 \mathrm{kPa}$ in humans) can promote adipogenesis (Rowlands et al., 2008; Young et al., 2013; Ghasemi-Mobarakeh et al., 2015), mimicking the elastic properties of skeletal muscles $(\sim 10 \mathrm{kPa})$ can promote myoblast fusion, and MSC differentiation to the muscle lineage (Discher et al., 2005; Engler et al., 2006; Rowlands et al., 2008; Lesman et al., 2011; Lapin et al., 2013; Loh and Choong, 2013; Ghasemi-Mobarakeh et al., 2015; Qazi et al., 2015; Perry et al., 2017b). Generating an intricate scaffold with several spatially organized cell niches, and a set of large pores for media perfusion, can mimic natural microenvironments found in the skeletal muscle and further modulate cell localization and differentiation (Zeltinger et al., 2001; Reilly and Engler, 2010; Park et al., 2011; Tse and Engler, 2011; Loh and Choong, 2013).

\section{Hydrogels}

Hydrogels are ubiquitous in the field of tissue engineering, as they can mimic the 3D environment of the ECM. As such, they are designed with the consideration of their mechanical properties, cytocompatibility, mass transport and degradation kinetics (Drury and Mooney, 2003; Redaelli et al., 2017).
Hydrogels can be used as a soft scaffold, as a source material for macroporous scaffolds, or as an ECM-like biomaterial that fills voids of the macroporous scaffolds (Drury and Mooney, 2003; Yegappan et al., 2018). For the latter, hydrogel polymerization must occur after cell seeding, using a cell-compatible solution and protocol (Drury and Mooney, 2003; Redaelli et al., 2017). The gelation kinetics and technique must be scalable, and allow for homogenous gelation throughout the construct (Ruel-Gariépy and Leroux, 2004; Redaelli et al., 2017).

Hydrogels can be used to produce bio-artificial muscles (BAMs) - strips of engineered skeletal muscle tissues. These constructs can be produced by seeding satellite cells inside a gel, anchored from both sides to mimic tension exerted by tendons (Post, 2012). Like macroporous scaffolds, the anchor points define the dimensions of the tissue and provide it with mechanical support. Over time, the gel shrinks and tension builds up in the BAM, which promotes myotube fusion and protein synthesis (Post and van der Weele, 2014). Gholobova et al. (2015) optimized BAM vascularization, showing fibrin gel is sufficient to form vascularized BAMs. Post (2014) generated circular muscle strips inside collagen/matrigel around hubs of agarose gel. Ten thousand of these strips were required to produce an 85 -gram burger.

In order to recapitulate muscle ECM, hydrogels for clean meat should be made from pre-synthesized ECM, polysaccharides or fibrous proteins. Hydrogels commonly used for skeletal muscle tissue engineering are comprised of biopolymers such as fibrin, collagen, or polysaccharides such as HA, alginate, agarose and chitosan (Drury and Mooney, 2003; Shit and Shah, 2014; Qazi et al., 2015; Wolf et al., 2015).

Fibrin is a naturally occurring fibrous protein that forms blood clots in injury sites. It is biologically designed to be a temporary scaffold for de-novo tissue regeneration in-vivo, which can degrade over days in cell media (Jockenhoevel et al., 2001; van Hinsbergh et al., 2001). As such, it is commonly used as a hydrogel for muscle tissue engineering (Koning et al., 2009). Fibrin gel is generated under the thrombin-mediated enzymatic cleavage of fibrinogen, which can be expressed in $\mathrm{CHO}$ cells (Harrysson and Lövgren, 2012; Hirashima et al., 2016).

Collagen and HA are naturally found in the muscle ECM. As such, they can be used to mimic some of the biochemical and biophysical properties of the native ECM, and are also susceptible to remodeling and degradation by the cells, crucial for cell migration and ECM maturation (Drury and Mooney, 2003). Collagen is often used in tissue engineering, as it is the most abundant protein in the body. The fibrous collagens I and III are abundant in the muscle ECM. They serve structural roles in the tissues, as anchoring points for cell adhesion, and facilitate cell migration and tissue development (Sweeney et al., 2008; Fuoco et al., 2016). However, collagen generates planar structures in the ECM (Purslow, 2014), and due to their high tensile strength, collagen hydrogels are mostly used to generate mechanically stable, cell adhesive, macroporous scaffolds (Drury and Mooney, 2003; Kadler et al., 2007). A collagen-fibrin mixture can be used as a hydrogel for muscle regeneration, which has been shown to promote cell proliferation and myotube differentiation (Beier et al., 2009). 
HA is a simple GAG ubiquitous in the body and in the muscle ECM. It participates in wound healing and can regulate cell behavior, such as adipogenesis, angiogenesis and tissue organization (Colwell et al., 2003; Halbleib et al., 2003; Allison and Grande-Allen, 2006; Davidenko et al., 2010; Chang et al., 2013). HA hydrogels are cell-compatible, show favorable viscoelastic properties, have high water retention, and can be synthesized in animal-free platforms (Sze et al., 2016). HAcollagen composites show improved mechanical and biological properties, and can be used for adipogenesis scaffolding (Drury and Mooney, 2003; Allison and Grande-Allen, 2006; Davidenko et al., 2010; Chang et al., 2013).

Alginate is an inexpensive seaweed-based polysaccharide which forms hydrogels in the presence of $\mathrm{Ca}^{+2}$. It is composed of two monomers, one of which interacts with $\mathrm{Ca}^{+2}$, making crosslink degree highly tunable (Drury and Mooney, 2003). Since alginate is cell-inert, it is routinely functionalized with RGD peptides that provide anchoring points for cell attachment. Tuning the monomer ratio and RGD concentration can improve myoblast proliferation and differentiation (Rowley and Mooney, 2002). Alginate hydrogels were recently used as a scaffold for bovine adipogenesis (Mehta et al., 2019) While alginate cannot be remodeled or degraded by cells, degradation kinetics can be controlled by modifying its structure (Drury and Mooney, 2003). Alginate-HA composites can improve the regenerative properties of the alginate gel, while providing improved gelation compared to HA alone (Oerther et al., 1999).

Chitosan is an edible glucoseamine polymer, used in skeletal muscle tissue engineering (Qazi et al., 2015; Wolf et al., 2015). It is commonly derived from animals, however, can also be produced from mushrooms (Mesa Ospina et al., 2015). Chitosan provide similar structure to GAGs, and can provide antibacterial properties (Fedorovich et al., 2007), however like alginate, it requires chemical modification to facilitate cell adhesion and biodegradability (Huang et al., 2017). Jana et al. (2013) used chitosan scaffolds to generate uniaxial scaffolds with tuned stiffness, resulting in long $(500 \mu \mathrm{m})$ and thick $(50 \mu \mathrm{m})$ mouse myotubes that express MHC. Chitosan biopolymers could also be used to optimize the gel's mechanical properties (Enrione et al., 2013).

\section{GENE EXPRESSION}

Gene expression tools are often used to study metabolic pathways in farm animals, particularly of IMF. These works are highly valuable for clean meat research, as they are not aimed for regenerative medicine, but rather focus on meat traits, such as marbling (Lee et al., 2010; Sadkowski et al., 2014; Chen et al., 2015; Hudson et al., 2015; Meadus et al., 2018), myogenesis (Wang et al., 2005, 2015; Lee et al., 2014; Dai et al., 2016), and sensory qualities (Bernard et al., 2007; Hocquette et al., 2007; Bongiorni et al., 2016; Tizioto et al., 2016). Research on correlations between gene expression and meat quality has been recently summarized in several publications. Linde (2018) published a table (table 2.5) of bovine genes and their corresponding meat traits. Guo and Dalrymple
(2017) elaborated on genes which correlate with adipogenesis, lipogenesis, fatty acid composition, meat tenderness, and the connection between ECM and IMF. Picard et al. (2015) elaborated on proteomics, transcriptomic and metabolomics works conducted in bovine, chicken, and porcine. The paper provides a list of biomarkers for beef tenderness and gene clusters with their corresponding pork qualities. It should be noted that most of these works are performed in meat from whole animals, and that the data found in such complicated biological systems may include additional pathways which are irrelevant for clean meat research. In addition, most of these studies are comparative, with the aim of finding novel genes. As such, key genes with similar levels of expression are left unreported.

Gene expression can be measured on three levels of complexity using qRNA, microarrays and RNA sequencing (RNA-seq). qRNA quantifies several genes of interest and can be used to monitor the expression of key biomarkers when a deep understanding of the system is not required. Ramírez-Espinosa et al. (2016) provide a list of PCR primers designed to assess bovine myogenesis, adipogenesis and stemness. Microarrays quantify $10^{1}-10^{6}$ known RNA transcripts, and can be used to obtain an overview of gene expression patterns in muscle and fat (Wang et al., 2005; Tan et al., 2006). Genome-wide microarrays, which were used to profile gene expression in fat and muscle, are commercially available from Affymetrix and Agilent for bovine (Lee et al., 2010; Cassar-Malek et al., 2017; Hayashi et al., 2018; Liu et al., 2018), ovine (Liu et al., 2015; González-Calvo et al., 2017), porcine (Fontanesi et al., 2011; González-Prendes et al., 2017a,b) and chicken (Du et al., 2017; Zahoor et al., 2017; Chang et al., 2018) samples, however may be too expensive and provide an overwhelming volume of data for routine sample assessment. Additional commercial products for porcine samples were summarized by Pena et al. (2014), including microarrays specific for muscle. A customized bovine muscle/fat microarray with 9.6K probes was developed in 2005 (Lehnert et al., 2005). As with the genome-wide microarrays, it was mainly used to detect correlations between muscle traits and relevant biomarkers (Wang et al., 2005, 2009; Lehnert et al., 2007), but was also used to track transcriptomic changes during bovine adipogenesis invitro (Tan et al., 2006). However, this microarray was developed from a 2-year-old muscle and subcutaneous adipose tissue, and therefore, may miss specific genes expressed only in early developmental stages. RNA-seq is another genomic technique which quantifies the entire transcriptome de novo. Since this label-free technique requires minimal knowledge of the species at hand, it is advantageous for preliminary research of new exotic species or unknown RNA transcripts. Using this approach Sun et al. (2016) discovered a long non-coding RNA molecule that promotes myogenesis in bovine muscle by upregulating IGF-II expression. However RNA-seq is expensive, requires tedious analysis, and is less accurate for miRNA quantification (Horodyska et al., 2018), making it less pragmatic for clean meat research of extensively studied species (Reverter et al., 2006; Wickramasinghe et al., 2014).

miRNA, short RNA molecules that inhibit genes with complementary mRNA, play a crucial role in the regulation of 
TABLE 1 | Additional reading materials.

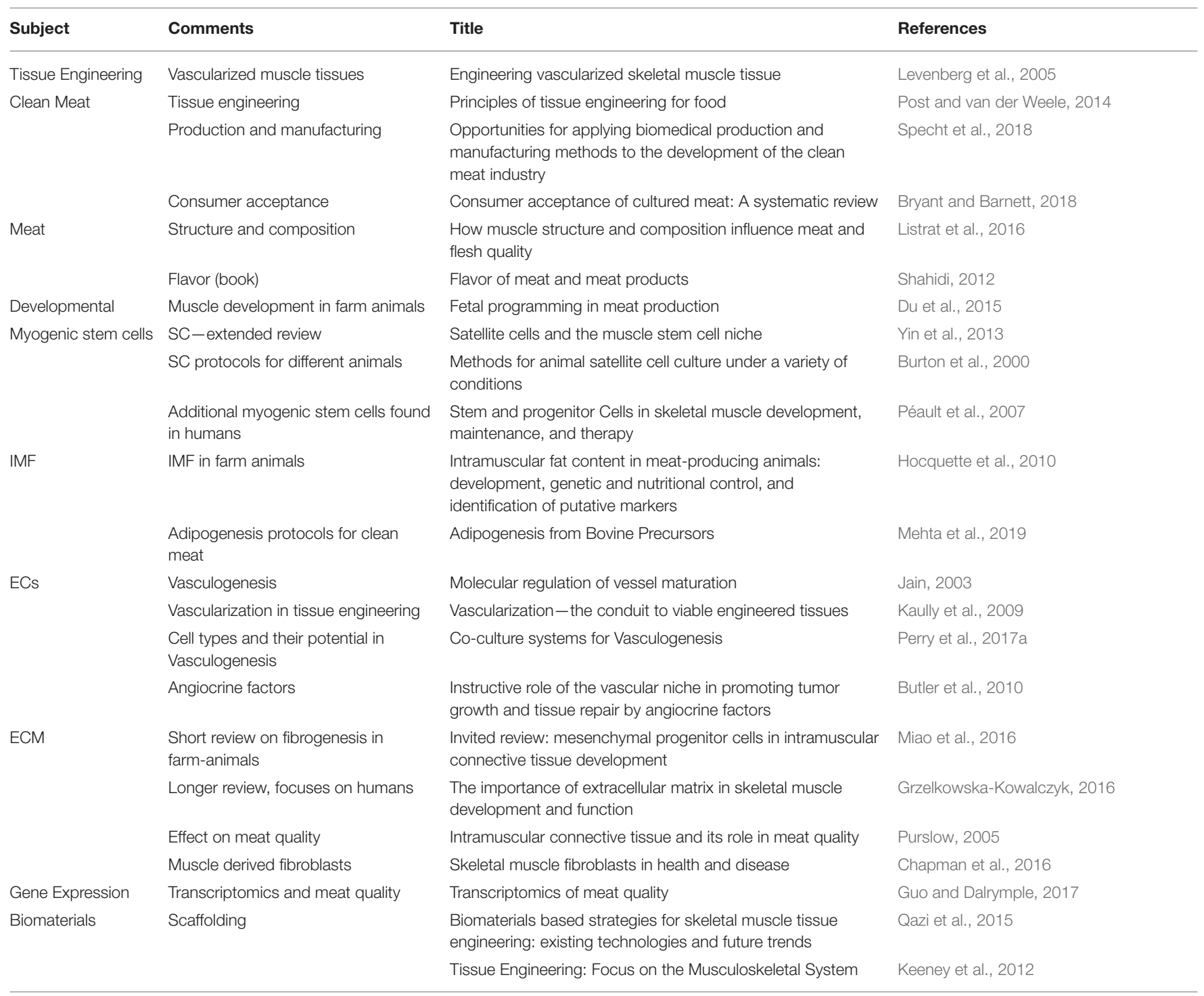

muscle tissue development, including myogenesis (Wang et al., 2015; Dai et al., 2016; Zhang et al., 2017; Sadkowski et al., 2018) and adipogenesis (Yan et al., 2013). Several naturally occurring miRNA molecules have been shown to regulate myogenesis and adipogenesis in farm animals, including regulation of PPARG and C/EBP $\alpha$ expression (Romao et al., 2011) and lipid metabolism (Wilfred et al., 2007).

Protein expression can be measured using mass spectrometry. This can reveal novel biomarkers, such as tenderness and hypertrophy biomarkers (Picard et al., 2015), and provide a more reliable quantification of biological pathways (Poleti et al., 2018), especially regarding ECM deposition and posttranslational modification (Chen et al., 2019), as compared to RNA measurements. Several reviews were published regarding proteomics and farm animals skeletal muscle research, discussing biomarkers and metabolic pathways, which are related to myogenesis, hypertrophy and meat traits, including flavor, tenderness, color, water holding capacity and $\mathrm{pH}$ (Picard et al., 2010, 2011; Bendixen et al., 2011; Veiseth-Kent et al., 2018).

\section{CONCLUSION}

Tissue engineering is a promising platform for creation of meat in a controlled, animal-free environment. It requires a shift in optimization parameters, with greater emphasis on inexpensive, animal-free biomaterials, efficient expansion of farm animal cells, tissue engineering of intramuscular fat, and analysis methods focusing on nutritional value and organoleptic properties. Implementation of tools and knowledge from the fields of food engineering and meat science will help develop novel research opportunities, such as tissue engineering of intramuscular fat or the generation of novel flavor-enhancing scaffolds. Clean meat scaffolds should be generated from edible biomaterials and designed to mimic the connective 
tissues of the muscle. Finally, multicellular seeding of muscle cells, fibroblasts, ECs and adipocytes inside such scaffolds can yield engineered muscle tissues with meat-like properties. Additional recommended reading materials can be found in Table 1.

\section{AUTHOR CONTRIBUTIONS}

TB-A conducted the literature survey, collated the relevant information, and wrote the paper with SL.

\section{REFERENCES}

Aldridge, A., Kouroupis, D., Churchman, S., English, A., Ingham, E., and Jones, E. (2013). Assay validation for the assessment of adipogenesis of multipotential stromal cells-a direct comparison of four different methods. Cytotherapy 15, 89-101. doi: 10.1016/j.jcyt.2012.07.001

Allen, R. E., and Boxhorn, L. K. (1989). Regulation of skeletal muscle satellite cell proliferation and differentiation by transforming growth factor-beta, insulinlike growth factor I, and fibroblast growth factor. J. Cell. Physiol. 138, 311-315. doi: $10.1002 /$ jcp. 1041380213

Allison, D. D., and Grande-Allen, K. J. (2006). Review. Hyaluronan: a powerful tissue engineering tool. Tissue Eng. 12, 2131-2140. doi: 10.1089/ten.2006.12.2131

Allt, G., and Lawrenson, J. G. (2001). Pericytes: cell biology and pathology. Cells Tissues Organs 169, 1-11. doi: 10.1159/000047855

Anderson, S. (2007). Determination of fat, moisture, and protein in meat and meat products by using the FOSS FoodScan near-infrared spectrophotometer with FOSS artificial neural network calibration model and associated database: collaborative study. J. AOAC Int. 90, 1073-1083.

Anomaly, J. (2015). What's wrong with factory farming? Public Health Ethics 8, 246-254. doi: 10.1093/phe/phu001

Austin, L., and Burgess, A. W. (1991). Stimulation of myoblast proliferation in culture by leukaemia inhibitory factor and other cytokines. J. Neurol. Sci. 101, 193-197. doi: 10.1016/0022-510X(91)90045-9

Avesar, J., Rosenfeld, D., Truman-Rosentsvit, M., Ben-Arye, T., Geffen, Y., Bercovici, M., et al. (2017). Rapid phenotypic antimicrobial susceptibility testing using nanoliter arrays. Proc. Natl. Acad. Sci. U.S.A. 114, E5787 -E5795. doi: 10.1073/pnas.1703736114

Aviss, K. J., Gough, J. E., and Downes, S. (2010). Aligned electrospun polymer fibres for skeletal muscle regeneration. Eur. Cell. Mater. 19, 193-204. doi: 10.22203/eCM.v019a19

Baum, J., and Duffy, H. S. (2011). Fibroblasts and myofibroblasts: what are we talking about? J. Cardiovasc. Pharmacol. 57, 376-379. doi: 10.1097/FJC.0b013e3182116e39

Beier, J. P., Klumpp, D., Rudisile, M., Dersch, R., Wendorff, J. H., Bleiziffer, O., et al. (2009). Collagen matrices from sponge to nano: new perspectives for tissue engineering of skeletal muscle. BMC Biotechnology 9:34. doi: 10.1186/1472-6750-9-34

Bendixen, E., Danielsen, M., Hollung, K., Gianazza, E., and Miller, I. (2011). Farm animal proteomics-a review. J. Proteomics 74, 282-293. doi: 10.1016/j.jprot.2010.11.005

Bergers, G., and Song, S. (2005). The role of pericytes in blood-vessel formation and maintenance. Neuro. Oncol. 7, 452-464. doi: 10.1215/S11528517050 00232

Bernard, C., Cassar-Malek, I., Le Cunff, M., Dubroeucq, H., Renand, G., and Hocquette, J.-F. (2007). New indicators of beef sensory quality revealed by expression of specific genes. J. Agric. Food Chem. 55, 5229-5237. doi: 10.1021/jf063372l

Bogliotti, Y. S., Wu, J., Vilarino, M., Okamura, D., Soto, D. A., Zhong, C., et al. (2018). Efficient derivation of stable primed pluripotent embryonic stem cells from bovine blastocysts. Proc. Natl. Acad. Sci. U. S. A. 115, 2090-2095. doi: 10.1073/pnas.1716161115

\section{FUNDING}

This work was supported by funding from Aleph-Farms Ltd Israel.

\section{ACKNOWLEDGMENTS}

The authors wish to thank Alina Freiman for her graphical design assistance and Dr. Inbal Michael and Dr. Yehudit Posen for editorial assistance in preparing this manuscript.

Bonab, M. M., Alimoghaddam, K., Talebian, F., Ghaffari, S. H., Ghavamzadeh, A., and Nikbin, B. (2006). Aging of mesenchymal stem cell in vitro. BMC Cell Biol. 7:14. doi: 10.1186/1471-2121-7-14

Bongiorni, S., Gruber, C. E. M., Bueno, S., Chillemi, G., Ferrè, F., Failla, S., et al. (2016). Transcriptomic investigation of meat tenderness in two Italian cattle breeds. Anim. Genet. 47, 273-287. doi: 10.1111/age.12418

Boonen, K. J. M., Rosaria-Chak, K. Y., Baaijens, F. P. T., van der Schaft, D. W. J., and Post, M. J. (2009). Essential environmental cues from the satellite cell niche: optimizing proliferation and differentiation. Am. J. Physiol. Cell Physiol. 296, C1338-C1345. doi: 10.1152/ajpcell.00015.2009

Bosnakovski, D., Mizuno, M., Kim, G., Takagi, S., Okumura, M., and Fujinaga, T. (2005). Isolation and multilineage differentiation of bovine bone marrow mesenchymal stem cells. Cell Tissue Res. 319, 243-253. doi: 10.1007/s00441-004-1012-5

Brazile, B., Lin, S., Copeland, K. M., Butler, J. R., Cooley, J., BrinkmanFerguson, E., et al. (2017). "Chapter 6 - Ultrastructure and Biomechanics of Skeletal Muscle ECM: Implications in Tissue Regeneration," in Bio-Instructive Scaffolds for Musculoskeletal Tissue Engineering and Regenerative Medicine, eds J. L. Brown, S. G. Kumbar, and B. L. Banik (Academic Press), 139-160. doi: 10.1016/B978-0-12-803394-4.00006-9

Brett, E., Chung, N., Leavitt, W. T., Momeni, A., Longaker, M. T., and Wan, D. C. (2017). A review of cell-based strategies for soft tissue reconstruction. Tissue Eng. Part B Rev. 23, 336-346. doi: 10.1089/ten.teb. 2016.0455

Bridge, K. Y., Smith, C. K., and Young, R. B. (1998). Beta-adrenergic receptor gene expression in bovine skeletal muscle cells in culture. J. Anim. Sci. 76, 2382-2391. doi: $10.2527 / 1998.7692382 x$

Broad, G. M. (2018). Effective animal advocacy: effective altruism, the social economy, and the animal protection movement. Agric. Human Values. 35, 777-789. doi: 10.1007/s10460-018-9873-5

Broom, D. M. (1991). Animal welfare: concepts and measurement. J. Anim. Sci. 69, 4167-4175. doi: 10.2527/1991.69104167x

Broom, D. M., and Fraser, A. F. (2015). Domestic Animal Behaviour and Welfare, 5th Edn. CABI. Available online at: https://books.google.co.il/books? $\mathrm{id}=-\mathrm{uEcCgAAQBAJ}$ (accessed September 13, 2018).

Bryant, C., and Barnett, J. (2018). Consumer acceptance of cultured meat: a systematic review. Meat Sci. 143, 8-17. doi: 10.1016/j.meatsci.2018. 04.008

Burton, N. M., Vierck, J., Krabbenhoft, L., Bryne, K., and Dodson, M. V. (2000). Methods for animal satellite cell culture under a variety of conditions. Methods Cell Sci. 22, 51-61. doi: 10.1023/A:1009830114804

Butler, J. M., Kobayashi, H., and Rafii, S. (2010). Instructive role of the vascular niche in promoting tumour growth and tissue repair by angiocrine factors. Nat. Rev. Cancer 10, 138-146. doi: 10.1038/nrc2791

Cai, A., Horch, R. E., and Beier, J. P. (2017). "15 - Nanofiber composites in skeletal muscle tissue engineering," in Nanofiber Composites for Biomedical Applications, eds M. Ramalingam and S. Ramakrishna (Woodhead Publishing), 369-394. doi: 10.1016/B978-0-08-100173-8.00015-6

Calkins, C. R., and Hodgen, J. M. (2007). A fresh look at meat flavor. Meat Sci. 77, 63-80. doi: 10.1016/j.meatsci.2007.04.016

Cao, Y. (2007). Angiogenesis modulates adipogenesis and obesity. J. Clin. Invest. 117, 2362-2368. doi: 10.1172/JCI32239 
Cao, Y. (2013). Angiogenesis and vascular functions in modulation of obesity, adipose metabolism, and insulin sensitivity. Cell Metab. 18, 478-489. doi: 10.1016/j.cmet.2013.08.008

Cardoso, T. C., Ferrari, H. F., Garcia, A. F., Novais, J. B., Silva-Frade, C., Ferrarezi, M. C., et al. (2012). Isolation and characterization of Wharton's jellyderived multipotent mesenchymal stromal cells obtained from bovine umbilical cord and maintained in a defined serum-free three-dimensional system. $B M C$ Biotechnol. 12:18. doi: 10.1186/1472-6750-12-18

Cassar-Malek, I., Boby, C., Picard, B., Reverter, A., and Hudson, N. J. (2017). Molecular regulation of high muscle mass in developing Blonde d'Aquitaine cattle fetuses. Biol. Open 6, 1483-1492. doi: 10.1242/bio.024950

Chal, J., and Pourquié, O. (2017). Making muscle: skeletal myogenesis in vivo and in vitro. Development 144, 2104-2122. doi: 10.1242/dev.151035

Chang, K.-H., Liao, H.-T., and Chen, J.-P. (2013). Preparation and characterization of gelatin/hyaluronic acid cryogels for adipose tissue engineering: in vitro and in vivo studies. Acta Biomater. 9, 9012-9026. doi: 10.1016/j.actbio.2013. 06.046

Chang, W. H., Zheng, A. J., Chen, Z. M., Zhang, S., Cai, H. Y., and Liu, G. H. (2018). $\beta$-Casomorphin increases fat deposition in broiler chickens by modulating expression of lipid metabolism genes. Animal 13, 777-783. doi: $10.1017 /$ S1751731118002197

Chapman, M. A., Meza, R., and Lieber, R. L. (2016). Skeletal muscle fibroblasts in health and disease. Differentiation 92, 108-115. doi: 10.1016/j.diff.2016. 05.007

Chaturvedi, V., Dye, D. E., Kinnear, B. F., van Kuppevelt, T. H., Grounds, M. D., and Coombe, D. R. (2015). Interactions between skeletal muscle myoblasts and their extracellular matrix revealed by a serum free culture system. PLOS ONE 10:e0127675. doi: 10.1371/journal.pone.0127675

Chen, D., Li, W., Du, M., Wu, M., and Cao, B. (2015). Sequencing and characterization of divergent marbling levels in the beef cattle (Longissimus dorsi Muscle) transcriptome. Asian-australas. J. Anim. Sci. 28, 158 -165. doi: 10.5713/ajas.14.0394

Chen, F.-F., Wang, Y.-Q., Tang, G.-R., Liu, S.-G., Cai, R., Gao, Y., et al. (2018). Differences between porcine longissimus thoracis and semitendinosus intramuscular fat content and the regulation of their preadipocytes during adipogenic differentiation. Meat Sci. 147, 116-126. doi: 10.1016/j.meatsci.2018.09.002

Chen, L., Li, Z., Everaert, N., Lametsch, R., and Zhang, D. (2019). Quantitative phosphoproteomic analysis of ovine muscle with different postmortem glycolytic rates. Food Chem. 280, 203-209. doi: 10.1016/j.foodchem.2018.12.056

Chen, L., Todd, R., Kiehlbauch, J., Walters, M., and Kallen, A. (2017). Notes from the field: pan-resistant new delhi metallo-beta-lactamase-producing klebsiella pneumoniae - washoe county, nevada, 2016. MMWR Morb. Mortal. Wkly. Rep. 66:33. doi: 10.15585/mmwr.mm6601a7

Chen, Y., Bloemen, V., Impens, S., Moesen, M., Luyten, F. P., and Schrooten, J. (2011). Characterization and optimization of cell seeding in scaffolds by factorial design: quality by design approach for skeletal tissue engineering. Tissue Eng. Part C Methods 17, 1211-1221. doi: 10.1089/ten.tec.2011.0092

Chien, K. B., Makridakis, E., and Shah, R. N. (2013). Three-dimensional printing of soy protein scaffolds for tissue regeneration. Tissue Eng. Part C Methods 19, 417-426. doi: 10.1089/ten.tec.2012.0383

Choi, J. S., Lee, S. J., Christ, G. J., Atala, A., and Yoo, J. J. (2008). The influence of electrospun aligned poly(epsilon-caprolactone)/collagen nanofiber meshes on the formation of self-aligned skeletal muscle myotubes. Biomaterials 29 , 2899-2906. doi: 10.1016/j.biomaterials.2008.03.031

Christov, C., Chrétien, F., Abou-Khalil, R., Bassez, G., Vallet, G., Authier, F.-J., et al. (2007). Muscle satellite cells and endothelial cells: close neighbors and privileged partners. Mol. Biol. Cell 18, 1397-1409. doi: 10.1091/mbc.e06-08-0693

Ciccone, J. (2015). Angioadaptive Allies: Examining the Relationship Between Endothelial Cells and Human Skeletal Muscle Myofibroblasts. Available online at: http://yorkspace.library.yorku.ca/xmlui/handle/10315/30133

Claeys, E., De Smet, S., Balcaen, A., Raes, K., and Demeyer, D. (2004). Quantification of fresh meat peptides by SDS-PAGE in relation to ageing time and taste intensity. Meat Sci. 67, 281-288. doi: 10.1016/j.meatsci.2003.11.001

Colwell, A. S., Longaker, M. T., and Lorenz, H. P. (2003). Fetal wound healing. Front. Biosci. 8, s1240-8. doi: 10.2741/1183
Conley, A. J., Joensuu, J. J., Menassa, R., and Brandle, J. E. (2009). Induction of protein body formation in plant leaves by elastin-like polypeptide fusions. $B M C$ Biol. 7:48. doi: 10.1186/1741-7007-7-48

Cosgrove, B. D., Sacco, A., Gilbert, P. M., and Blau, H. M. (2009). A home away from home: challenges and opportunities in engineering in vitro muscle satellite cell niches. Differentiation 78, 185-194. doi: 10.1016/j.diff.2009.08.004

Council, A. C. A. (2010). Contribution of the Pet Care Industry to the Australian Economy. East Hartford, CT: Rockwell Communications. Available online at: https://www.paws4play.com.au/pdfs/2010-Bis-Shrapnel-EconomPet-Benefits. pdf

Courtenay, J. C., Sharma, R. I., and Scott, J. L. (2018). Recent advances in modified cellulose for tissue culture applications. Molecules 23:E654. doi: 10.3390/molecules23030654

Cui, H. X., Guo, L. P., Zhao, G. P., Liu, R. R., Li, Q. H., Zheng, M. Q., et al. (2018). Method using a co-culture system with high-purity intramuscular preadipocytes and satellite cells from chicken pectoralis major muscle. Poult. Sci. 97, 3691-3697. doi: 10.3382/ps/pey023

Daamen, W. F., van Moerkerk, H. T. B., Hafmans, T., Buttafoco, L., Poot, A. A., Veerkamp, J. H., et al. (2003). Preparation and evaluation of molecularlydefined collagen-elastin-glycosaminoglycan scaffolds for tissue engineering. Biomaterials 24, 4001-4009. doi: 10.1016/S0142-9612(03)00273-4

Dai, Y., Zhang, W. R., Wang, Y. M., Liu, X. F., Li, X., Ding, X. B., et al. (2016). MicroRNA-128 regulates the proliferation and differentiation of bovine skeletal muscle satellite cells by repressing Sp1. Mol. Cell. Biochem. 414, 37-46. doi: 10.1007/s11010-016-2656-7

D’Alessandro, A., Rinalducci, S., Marrocco, C., Zolla, V., Napolitano, F., and Zolla, L. (2012). Love me tender: an Omics window on the bovine meat tenderness network. J. Proteomics 75, 4360-4380. doi: 10.1016/j.jprot.2012.02.013

Damez, J.-L., and Clerjon, S. (2013). Quantifying and predicting meat and meat products quality attributes using electromagnetic waves: an overview. Meat Sci. 95, 879-896. doi: 10.1016/j.meatsci.2013.04.037

Davidenko, N., Campbell, J. J., Thian, E. S., Watson, C. J., and Cameron, R. E. (2010). Collagen-hyaluronic acid scaffolds for adipose tissue engineering. Acta Biomater. 6, 3957-3968. doi: 10.1016/j.actbio.2010.05.005

Dawkins, M. S. (2006). Through animal eyes: What behaviour tells us. Appl. Anim. Behav. Sci. 100, 4-10. doi: 10.1016/j.applanim.2006. 04.010

De Deyne, P. G. (2000). Formation of sarcomeres in developing myotubes: role of mechanical stretch and contractile activation. Am. J. Physiol. Cell Physiol. 279, C1801-C1811. doi: 10.1152/ajpcell.2000.279.6.C1801

Ding, S., Swennen, G. N. M., Messmer, T., Gagliardi, M., Molin, D. G. M., Li, C., et al. (2018). Maintaining bovine satellite cells stemness through p38 pathway. Sci. Rep. 8:10808. doi: 10.1038/s41598-018-28746-7

Discher, D. E., Janmey, P., and Wang, Y.-L. (2005). Tissue cells feel and respond to the stiffness of their substrate. Science 310, 1139-1143. doi: 10.1126/science.1116995

Dodson, M. V., Allen, R. E., Du, M., Bergen, W. G., Velleman, S. G., Poulos, S. P., et al. (2015). INVITED REVIEW: evolution of meat animal growth research during the past 50 years: adipose and muscle stem cells. J. Anim. Sci. 93, 457-481. doi: 10.2527/jas.2014-8221

Dodson, M. V., Martin, E. L., Brannon, M. A., Mathison, B. A., and McFarland, D. C. (1987). Optimization of bovine satellite cell-derived myotube formation in vitro. Tissue Cell 19, 159-166.

Dodson, M. V., Vierck, J. L., Hossner, K. L., Byrne, K., and McNamara, J. P. (1997). The development and utility of a defined muscle and fat co-culture system. Tissue Cell 29, 517-524.

Drury, J. L., and Mooney, D. J. (2003). Hydrogels for tissue engineering: scaffold design variables and applications. Biomaterials 24, 4337-4351. doi: 10.1016/S0142-9612(03)00340-5

Du, M., Huang, Y., Das, A. K., Yang, Q., and Duarte, M. S. (2013). Manipulating mesenchymal progenitor cell differentiation to optimize performance and carcass value of beef cattle. J. Anim. Sci. 91, 1419-1427. doi: $10.2527 /$ jas.2012-5670

Du, M., Tong, J., Zhao, J., Underwood, K. R., Zhu, M., Ford, S. P., et al. (2010a). Fetal programming of skeletal muscle development in ruminant animals. $J$. Anim. Sci. 88, E51-60. doi: 10.2527/jas.2009-2311

Du, M., Wang, B., Fu, X., Yang, Q., and Zhu, M.-J. (2015). Fetal programming in meat production. Meat Sci. 109, 40-47. doi: 10.1016/j.meatsci.2015.04.010 
Du, M., Yin, J., and Zhu, M. J. (2010b). Cellular signaling pathways regulating the initial stage of adipogenesis and marbling of skeletal muscle. Meat Sci. 86, 103-109. doi: 10.1016/j.meatsci.2010.04.027

Du, Y. F., Ding, Q. L., Li, Y. M., and Fang, W. R. (2017). Identification of differentially expressed genes and pathways for myofiber characteristics in soleus muscles between chicken breeds differing in meat quality. Anim. Biotechnol. 28, 83-93. doi: 10.1080/10495398.2016.1206555

Duffy, R. M., Sun, Y., and Feinberg, A. W. (2016). Understanding the role of ecm protein composition and geometric micropatterning for engineering human skeletal muscle. Ann. Biomed. Eng. 44, 2076-2089. doi: 10.1007/s10439-016-1592-8

Duncan, I. J. H. (2006). The changing concept of animal sentience. Appl. Anim. Behav. Sci. 100, 11-19. doi: 10.1016/j.applanim.2006.04.011

Edelman, P. D., McFarland, D. C., Mironov, V. A., and Matheny, J. G. (2005). Commentary: In vitro-cultured meat production. Tissue Eng. 11, 659-662. doi: $10.1089 /$ ten.2005.11.659

Egozi, D., Shandalov, Y., Freiman, A., Rosenfeld, D., Ben-Shimol, D., and Levenberg, S. (2016). Engineered vascularized muscle flap. J. Vis. Exp. e52984. doi: $10.3791 / 52984$

Elder, M., and Fischer, B. (2017). Focus on fish: a call to effective altruists. Essays Philos. 18:7. doi: 10.7710/1526-0569.1567

Elliott, K. (2015). Antibiotics on the Farm: Agriculture's Role in Drug Resistance. CGD Policy Paper 59. Available online at: https://www.cgdev.org/sites/default/ files/CGD-Policy-Paper-59-Elliott-Antibiotics-Farm- Agriculture-DrugResistance.pdf

Engler, A. J., Sen, S., Sweeney, H. L., and Discher, D. E. (2006). Matrix elasticity directs stem cell lineage specification. Cell 126, 677-689. doi: 10.1016/j.cell.2006.06.044

Enrione, J., Díaz-Calderón, P., Weinstein-Oppenheimer, C. R., Sánchez, E., Fuentes, M. A., Brown, D. I., et al. (2013). Designing a gelatin/chitosan/hyaluronic acid biopolymer using a thermophysical approach for use in tissue engineering. Bioprocess Biosyst. Eng. 36, 1947-1956. doi: 10.1007/s00449-013-0971-x

Eom, J., Feisst, V., Ranjard, L., Loomes, K., Damani, T., Jackson-Patel, V., et al. (2018). Visualization and quantification of mesenchymal cell adipogenic differentiation potential with a lineage specific marker. J. Vis. Exp. 133:e57153. doi: $10.3791 / 57153$

Eshel, G., Shepon, A., Makov, T., and Milo, R. (2014). Land, irrigation water, greenhouse gas, and reactive nitrogen burdens of meat, eggs, and dairy production in the United States. Proc. Natl. Acad. Sci. U. S. A. 111, 11996-12001. doi: 10.1073/pnas.1402183111

Fedorovich, N. E., Alblas, J., de Wijn, J. R., Hennink, W. E., Verbout, A. J., and Dhert, W. J. A. (2007). Hydrogels as extracellular matrices for skeletal tissue engineering: state-of-the-art and novel application in organ printing. Tissue Eng. 13, 1905-1925. doi: 10.1089/ten.2006.0175

Flachowsky, G., Meyer, U., and Südekum, K.-H. (2018). Invited review: Resource inputs and land, water and carbon footprints from the production of edible protein of animal origin. Arch. Anim. Breed. 61, 17-36. doi: 10.5194/aab-61-17-2018

Fontanesi, L., Galimberti, G., Calò, D. G., Colombo, M., Astolfi, A., Formica, S., et al. (2011). Microarray gene expression analysis of porcine skeletal muscle sampled at several post mortem time points. Meat Sci. 88, 604-609. doi: 10.1016/j.meatsci.2011.02.001

Forbes, S. J., and Rosenthal, N. (2014). Preparing the ground for tissue regeneration: from mechanism to therapy. Nat. Med. 20, 857-869. doi: $10.1038 / \mathrm{nm} .3653$

Freiman, A., Shandalov, Y., Rosenfeld, D., Shor, E., Ben-David, D., Meretzki, S., et al. (2018). Engineering vascularized flaps using adipose-derived microvascular endothelial cells and mesenchymal stem cells. J. Tissue Eng. Regen. Med. 12, e130-e141. doi: 10.1002/term.2436

Frey, R. S., Johnson, B. J., Hathaway, M. R., White, M. E., and Dayton, W. R. (1995). Growth factor responsiveness of primary satellite cell cultures from steers implanted with trenbolone acetate and estradiol-17ß. Basic Appl. Myol. $5,71-79$.

Friedman, N. D., Temkin, E., and Carmeli, Y. (2016). The negative impact of antibiotic resistance. Clin. Microbiol. Infect. 22, 416-422. doi: $10.1016 /$ j.cmi.2015.12.002
Fu, S., Zhao, Y., Li, Y., Li, G., Chen, Y., Li, Z., et al. (2018). Characterization of miRNA transcriptome profiles related to breast muscle development and intramuscular fat deposition in chickens. J. Cell. Biochem. 119, 7063-7079. doi: $10.1002 /$ jcb. 27024

Fuoco, C., Petrilli, L. L., Cannata, S., and Gargioli, C. (2016). Matrix scaffolding for stem cell guidance toward skeletal muscle tissue engineering. J. Orthop. Surg. Res. 11:86. doi: 10.1186/s13018-016-0421-y

Gasteratos, K. S., and Sherman, R. (2018). Consumer Interest Towards Clean Meat. Available online at: https://dash.harvard.edu/handle/1/34901168

Gaydhane, M. K., Mahanta, U., Sharma, C. S., Khandelwal, M., and Ramakrishna, S. (2018). Cultured meat: state of the art and future. Biomanufact. Rev. 3:1. doi: 10.1007/s40898-018-0005-1

Ge, Y., Sun, Y., and Chen, J. (2011). IGF-II is regulated by microRNA125b in skeletal myogenesis. J. Cell Biol. 192, 69-81. doi: 10.1083/jcb.2010 07165

Gerber, P. J., Steinfeld, H., Henderson, B., Mottet, A., Opio, C., Dijkman, J., et al. (2013). Tackling Climate Change Through Livestock: A Global Assessment of Emissions and Mitigation Opportunities. Rome: Food and Agriculture Organization of the United Nations (FAO).

Ghasemi-Mobarakeh, L., Prabhakaran, M. P., Tian, L., Shamirzaei-Jeshvaghani, E., Dehghani, L., and Ramakrishna, S. (2015). Structural properties of scaffolds: Crucial parameters towards stem cells differentiation. World J. Stem Cells 7 , 728-744. doi: 10.4252/wjsc.v7.i4.728

Gholobova, D., Decroix, L., Van Muylder, V., Desender, L., Gerard, M., Carpentier, G., et al. (2015). Endothelial network formation within human tissue-engineered skeletal muscle. Tissue Eng. Part A 21, 2548-2558. doi: 10.1089/ten.tea.2015.0093

Gilbert, T. W., Stolz, D. B., Biancaniello, F., Simmons-Byrd, A., and Badylak, S. F. (2005). Production and characterization of ECM powder: implications for tissue engineering applications. Biomaterials 26, 1431-1435. doi: 10.1016/j.biomaterials.2004.04.042

Gilbert-López, B., Valdés, A., Acunha, T., García-Cañas, V., Simó, C., and Cifuentes, A. (2017). "Foodomics: LC and LC-MS-based omics strategies in food science and nutrition," in Liquid Chromatography, 2nd Edn, eds S. Fanali, P. R. Haddad, C. F. Poole, M-L. Riekkola (Amsterdam: Elsevier), 267-299. doi: 10.1016/B978-0-12-805392-8.00010-4

Gillies, A. R., and Lieber, R. L. (2011). Structure and function of the skeletal muscle extracellular matrix. Muscle Nerve 44, 318-331. doi: 10.1002/mus. 22094

Gomillion, C. T., and Burg, K. J. L. (2006). Stem cells and adipose tissue engineering. Biomaterials 27, 6052-6063. doi: $10.1016 /$ j.biomaterials.2006.07.033

González-Calvo, L., Dervishi, E., Joy, M., Sarto, P., Martin-Hernandez, R., Serrano, M., et al. (2017). Genome-wide expression profiling in muscle and subcutaneous fat of lambs in response to the intake of concentrate supplemented with vitamin E. BMC Genomics 18:92. doi: 10.1186/s12864-016-3405-8

González-Prendes, R., Quintanilla, R., and Amills, M. (2017a). Investigating the genetic regulation of the expression of 63 lipid metabolism genes in the pig skeletal muscle. Anim. Genet. 48, 606-610. doi: 10.1111/age.12586

González-Prendes, R., Quintanilla, R., Cánovas, A., Manunza, A., Figueiredo Cardoso, T., Jordana, J., et al. (2017b). Joint QTL mapping and gene expression analysis identify positional candidate genes influencing pork quality traits. Sci. Rep. 7:39830. doi: 10.1038/srep39830

Goodwin, J. N., and Shoulders, C. W. (2013). The future of meat: a qualitative analysis of cultured meat media coverage. Meat Sci. 95, 445-450. doi: 10.1016/j.meatsci.2013.05.027

Gorraiz, C., Beriain, M. J., Chasco, J., and Insausti, K. (2002). Effect of aging time on volatile compounds, odor, and flavor of cooked beef from pirenaica and friesian bulls and heifers. J. Food Sci. 67, 916-922. doi: 10.1111/j.1365-2621.2002.tb09428.x

Gottipamula, S., Muttigi, M. S., Chaansa, S., Ashwin, K. M., Priya, N., Kolkundkar, U., et al. (2016). Large-scale expansion of pre-isolated bone marrow mesenchymal stromal cells in serum-free conditions. J. Tissue Eng. Regen. Med. 10, 108-119. doi: 10.1002/term.1713

Grahl, S., Palanisamy, M., Strack, M., Meier-Dinkel, L., Toepfl, S., and Mörlein, D. (2018). Towards more sustainable meat alternatives: How technical parameters 
affect the sensory properties of extrusion products derived from soy and algae. J. Clean. Prod. 198, 962-971. doi: 10.1016/j.jclepro.2018.07.041

Grant, A. C., Ortiz-Colòn, G., Doumit, M. E., and Buskirk, D. D. (2008). Optimization of in vitro conditions for bovine subcutaneous and intramuscular preadipocyte differentiation. J. Anim. Sci. 86, 73-82. doi: 10.2527/jas.2007-0379

Green, C. (2008). How to End 98\% of Animal Abuse in the Next 25 Years. Available online at: https://faunalytics.org/how-to-end-98-of-animal-abusein-the-next-25-years (accessed September 13, 2018).

Greger, M. (2007). The human/animal interface: emergence and resurgence of zoonotic infectious diseases. Crit. Rev. Microbiol. 33, 243-299. doi: $10.1080 / 10408410701647594$

Griffith, C. K., Miller, C., Sainson, R. C. A., Calvert, J. W., Jeon, N. L., Hughes, C. C. W., et al. (2005). Diffusion limits of an in vitro thick prevascularized tissue. Tissue Eng. 11, 257-266. doi: 10.1089/ten.2005.11.257

Grzelkowska-Kowalczyk, K. (2016). "The importance of extracellular matrix in skeletal muscle development and function," in Composition and Function of the Extracellular Matrix in the Human Body, ed. F. Travascio (InTech), 3-24. doi: $10.5772 / 62230$

Guan, L., Hu, X., Liu, L., Xing, Y., Zhou, Z., Liang, X., et al. (2017). bta-miR-23a involves in adipogenesis of progenitor cells derived from fetal bovine skeletal muscle. Sci. Rep. 7:43716. doi: 10.1038/srep43716

Guo, B., and Dalrymple, B. P. (2017). "Chapter 11 - Transcriptomics of Meat Quality," in New Aspects of Meat Quality, ed. P. P. Purslow (Woodhead Publishing), 259-320. doi: 10.1016/B978-0-08-100593-4.00012-6

Guo, B., Greenwood, P. L., Cafe, L. M., Zhou, G., Zhang, W., and Dalrymple, B. P. (2015). Transcriptome analysis of cattle muscle identifies potential markers for skeletal muscle growth rate and major cell types. BMC Genomics 16:177. doi: 10.1186/s12864-015-1403-x

Halbleib, M., Skurk, T., de Luca, C., von Heimburg, D., and Hauner, H. (2003). Tissue engineering of white adipose tissue using hyaluronic acid-based scaffolds. I: in vitro differentiation of human adipocyte precursor cells on scaffolds. Biomaterials 24, 3125-3132. doi: 10.1016/S0142-9612(03)00156-X

Harper, G. S., and Pethick, D. W. (2004). How might marbling begin? Aust. J. Exp. Agric. 44, 653-662. doi: 10.1071/EA02114

Harrysson, A., and Lövgren, A. (2012). Method for Production of Recombinant Human Thrombin. US Patent. Available online at: https://patentimages.storage. googleapis.com/5a/9b/7e/0754ac5cda8493/US8206967.pdf (accessed October 2, 2018).

Hausman, G. J. (2012). Meat Science and Muscle Biology Symposium: the influence of extracellular matrix on intramuscular and extramuscular adipogenesis. J. Anim. Sci. 90, 942-949. doi: 10.2527/jas.2011-4616

Hausman, G. J., and Poulos, S. (2004). Recruitment and differentiation of intramuscular preadipocytes in stromal-vascular cell cultures derived from neonatal pig semitendinosus muscles. J. Anim. Sci. 82, 429-437. doi: $10.2527 / 2004.822429 \mathrm{x}$

Hayashi, M., Kido, K., and Hodate, K. (2018). Microarray analysis of Longissimus thoracis muscle gene expressions in vitamin A-restricted Japanese Black steers in middle fattening stage. Anim. Sci. J. 89, 88-96. doi: 10.1111/asj.12898

Heher, P., Maleiner, B., Prüller, J., Teuschl, A. H., Kollmitzer, J., Monforte, X., et al. (2015). A novel bioreactor for the generation of highly aligned 3D skeletal muscle-like constructs through orientation of fibrin via application of static strain. Acta Biomater. 24, 251-265. doi: 10.1016/j.actbio.2015. 06.033

Hemmrich, K., von Heimburg, D., Rendchen, R., Di Bartolo, C., Milella, E., and Pallua, N. (2005). Implantation of preadipocyte-loaded hyaluronic acidbased scaffolds into nude mice to evaluate potential for soft tissue engineering. Biomaterials 26, 7025-7037. doi: 10.1016/j.biomaterials.2005.04.065

Herzog, H. (2016). Farm Animal Suffering Leaves a Bad Taste In Your Mouth. Psychol. Today. Available onlien at: https://works.bepress.com/harold-herzog/ 98/download/ (accessed October 03, 2018).

Hickey, R. J., Modulevsky, D. J., Cuerrier, C. M., and Pelling, A. E. (2018). Customizing the shape and microenvironment biochemistry of biocompatible macroscopic plant-derived cellulose scaffolds. ACS Biomater. Sci. Eng. 11, 3726-3736. doi: 10.1021/acsbiomaterials.8b00178

Hirashima, M., Imamura, T., Yano, K., Kawamura, R., Meta, A., Tokieda, Y., et al. (2016). High-level expression and preparation of recombinant human fibrinogen as biopharmaceuticals. J. Biochem. 159, 261-270. doi: $10.1093 / \mathrm{jb} / \mathrm{mvv} 099$
Hocquette, J.-F., Lehnert, S., Barendse, W., Cassar-Malek, I., and Picard, B. (2007). Recent advances in cattle functional genomics and their application to beef quality. Animal 1, 159-173. doi: 10.1017/S17517311076 58042

Hocquette, J. F., Gondret, F., Baéza, E., Médale, F., Jurie, C., and Pethick, D. W. (2010). Intramuscular fat content in meat-producing animals: development, genetic and nutritional control, and identification of putative markers. Animal 4, 303-319. doi: 10.1017/S1751731109991091

Hong, L., Peptan, I., Clark, P., and Mao, J. J. (2005). Ex vivo adipose tissue engineering by human marrow stromal cell seeded gelatin sponge. Ann. Biomed. Eng. 33, 511-517. doi: 10.1007/s10439-005-2510-7

Hopkins, P. D., and Dacey, A. (2008). Vegetarian meat: could technology save animals and satisfy meat eaters? J. Agric. Environ. Ethics 21, 579-596. doi: 10.1007/s10806-008-9110-0

Horodyska, J., Oster, M., Reyer, H., Mullen, A. M., Lawlor, P. G., Wimmers, K., et al. (2018). Analysis of meat quality traits and gene expression profiling of pigs divergent in residual feed intake. Meat Sci. 137, 265-274. doi: 10.1016/j.meatsci.2017.11.021

Huang, G., Li, F., Zhao, X., Ma, Y., Li, Y., Lin, M., et al. (2017). Functional and biomimetic materials for engineering of the threedimensional cell microenvironment. Chem. Rev. 117, 12764-12850. doi: 10.1021/acs.chemrev.7b00094

Huang, J., Huang, K., You, X., Liu, G., Hollett, G., Kang, Y., et al. (2018). Evaluation of tofu as a potential tissue engineering scaffold. J. Mater. Chem. B Mater. Biol. Med. 6, 1328-1334. doi: 10.1039/C7TB02852K

Huang, Y., Das, A. K., Yang, Q.-Y., Zhu, M.-J., and Du, M. (2012). Zfp423 promotes adipogenic differentiation of bovine stromal vascular cells. PLoS ONE 7:e47496. doi: 10.1371/journal.pone.0047496

Hudson, N. J., Reverter, A., Greenwood, P. L., Guo, B., Cafe, L. M., and Dalrymple, B. P. (2015). Longitudinal muscle gene expression patterns associated with differential intramuscular fat in cattle. Animal 9, 650-659. doi: $10.1017 /$ S1751731114002754

Hughes, D. (1995). Animal welfare: the consumer and the food industry. Br. Food J. 97, 3-7. doi: 10.1108/00070709510104529

Jaffe, E. A. (2012). Biology of Endothelial Cells. Available online at: https://books. google.co.in/books?id=Y6jSBwAAQBAJ\&redir_esc=y (accessed September 11, 2018).

Jain, R. K. (2003). Molecular regulation of vessel maturation. Nat. Med. 9, 685-693. doi: $10.1038 / \mathrm{nm} 0603-685$

Jain, R. K., Au, P., Tam, J., Duda, D. G., and Fukumura, D. (2005). Engineering vascularized tissue. Nat. Biotechnol. 23, 821-823. doi: 10.1038/nbt0705-821

Jana, S., Cooper, A., and Zhang, M. (2013). Chitosan scaffolds with unidirectional microtubular pores for large skeletal myotube generation. Adv. Healthc. Mater. 2, 557-561. doi: 10.1002/adhm.201200177

Jana, S., Levengood, S. K. L., and Zhang, M. (2016). Anisotropic materials for skeletal-muscle-tissue engineering. Adv. Mater. 28, 10588-10612. doi: 10.1002/adma.201600240

Jockenhoevel, S., Zund, G., Hoerstrup, S. P., Chalabi, K., Sachweh, J. S., Demircan, L., et al. (2001). Fibrin gel-advantages of a new scaffold in cardiovascular tissue engineering. Eur. J. Cardiothorac. Surg. 19, 424-430. doi: 10.1016/S1010-7940(01)00624-8

Jordan, G., Thomasius, R., Schröder, H., Wulf, J. S., Schlüter, O., Sumpf, B., et al. (2009). Non-invasive mobile monitoring of meat quality. J. für Verbrauchers. Lebensmittelsicher. 4, 7-14. doi: 10.1007/s00003-009-0389-1

Kadler, K. E., Baldock, C., Bella, J., and Boot-Handford, R. P. (2007). Collagens at a glance. J. Cell Sci. 120, 1955-1958. doi: 10.1242/jcs.03453

Kamanga-Sollo, E., Pampusch, M. S., Xi, G., White, M. E., Hathaway, M. R., and Dayton, W. R. (2004). IGF-I mRNA levels in bovine satellite cell cultures: effects of fusion and anabolic steroid treatment. J. Cell. Physiol. 201, 181-189. doi: $10.1002 /$ jcp. 20000

Kamanga-Sollo, E., White, M. E., Hathaway, M. R., Chung, K. Y., Johnson, B. J., and Dayton, W. R. (2008). Roles of IGF-I and the estrogen, androgen and IGFI receptors in estradiol-17 $\beta$ - and trenbolone acetate-stimulated proliferation of cultured bovine satellite cells. Domest. Anim. Endocrinol. 35, 88-97. doi: 10.1016/j.domaniend.2008.02.003

Kang, J. H., Gimble, J. M., and Kaplan, D. L. (2009). In vitro 3D model for human vascularized adipose tissue. Tissue Eng. Part A 15, 2227-2236. doi: $10.1089 /$ ten.tea.2008.0469 
Kaully, T., Kaufman-Francis, K., Lesman, A., and Levenberg, S. (2009). Vascularization-the conduit to viable engineered tissues. Tissue Eng. Part B Rev. 15, 159-169. doi: 10.1089/ten.teb.2008.0193

Keeney, M., Han, L.-H., Onyiah, S., and Yang, F. (2012). Tissue Engineering: Focus on the Musculoskeletal System. Biomaterials Science: An Integrated Clinical and Engineering Approach, 191. Available online at: https://books.google.co. in/books?id=kcoeYDazWgIC\&redir_esc=y (accessed October 02, 2018).

King, J. A., and Miller, W. M. (2007). Bioreactor development for stem cell expansion and controlled differentiation. Curr. Opin. Chem. Biol. 11, 394-398. doi: 10.1016/j.cbpa.2007.05.034

Kjaer, M. (2004). Role of extracellular matrix in adaptation of tendon and skeletal muscle to mechanical loading. Physiol. Rev. 84, 649-698. doi: 10.1152/physrev.00031.2003

Koffler, J., Kaufman-Francis, K., Shandalov, Y., Yulia, S., Egozi, D., Dana, E., et al. (2011). Improved vascular organization enhances functional integration of engineered skeletal muscle grafts. Proc. Natl. Acad. Sci. U. S. A. 108, 14789-14794. doi: 10.1073/pnas.1017825108

Kollias, H. D., and McDermott, J. C. (2008). Transforming growth factor- $\beta$ and myostatin signaling in skeletal muscle. J. Appl. Physiol. 104, 579-587. doi: 10.1152/japplphysiol.01091.2007

Koning, M., Harmsen, M. C., van Luyn, M. J. A., and Werker, P. M. N. (2009). Current opportunities and challenges in skeletal muscle tissue engineering. J. Tissue Eng. Regen. Med. 3, 407-415. doi: 10.1002/term.190

Koohmaraie, M., Kent, M. P., Shackelford, S. D., Veiseth, E., and Wheeler, T. L. (2002). Meat tenderness and muscle growth: is there any relationship? Meat Sci. 62, 345-352. doi: 10.1016/S0309-1740(02)00127-4

Kragstrup, T. W., Kjaer, M., and Mackey, A. L. (2011). Structural, biochemical, cellular, and functional changes in skeletal muscle extracellular matrix with aging. Scand. J. Med. Sci. Sports 21, 749-757. doi: 10.1111/j.1600-0838.2011.01377.x

Kramer, A., and Szczesniak, A. S. (eds). (1973). Texture Measurements of Foods: Psychophysical Fundamentals: Sensory, Mechanical, and Chemical Procedures, and Their Interrelationships. Dordrecht: Springer.

Kraus, N. A., Ehebauer, F., Zapp, B., Rudolphi, B., Kraus, B. J., and Kraus, D. (2016). Quantitative assessment of adipocyte differentiation in cell culture. Adipocyte 5, 351-358. doi: 10.1080/21623945.2016.1240137

Krieger, J., Park, B.-W., Lambert, C. R., and Malcuit, C. (2018). 3D skeletal muscle fascicle engineering is improved with TGF- $\beta 1$ treatment of myogenic cells and their co-culture with myofibroblasts. PeerJ 6:e4939. doi: 10.7717/peerj.4939

Kümmerer, K. (2003). Significance of antibiotics in the environment. J. Antimicrob. Chemother. 52, 5-7. doi: 10.1093/jac/dkg293

Kunz-Schughart, L. A., Schroeder, J. A., Wondrak, M., van Rey, F., Lehle, K., Hofstaedter, F., et al. (2006). Potential of fibroblasts to regulate the formation of three-dimensional vessel-like structures from endothelial cells in vitro. Am. J. Physiol. Cell Physiol. 290, C1385-C1398. doi: 10.1152/ajpcell.00248.2005

Laliotis, G. P., Bizelis, I., and Rogdakis, E. (2010). Comparative approach of the de novo fatty acid synthesis (Lipogenesis) between ruminant and non ruminant mammalian species: from biochemical level to the main regulatory lipogenic genes. Curr. Genomics 11, 168-183. doi: 10.2174/138920210791110960

Landau, S., Guo, S., and Levenberg, S. (2018). Localization of engineered vasculature within 3D tissue constructs. Front Bioeng Biotechnol 6:2. doi: 10.3389/fbioe.2018.00002

Landau, S., Szklanny, A. A., Yeo, G. C., Shandalov, Y., Kosobrodova, E., Weiss, A. S., et al. (2017). Tropoelastin coated PLLA-PLGA scaffolds promote vascular network formation. Biomaterials 122, 72-82. doi: 10.1016/j.biomaterials.2017.01.015

Langelaan, M. L. P., Boonen, K. J. M., Polak, R. B., Baaijens, F. P. T., Post, M. J., and van der Schaft, D. W. J. (2010). Meet the new meat: tissue engineered skeletal muscle. Trends Food Sci. Technol. 21, 59-66. doi: 10.1016/j.tifs.2009. 11.001

Langelaan, M. L. P., Boonen, K. J. M., Rosaria-Chak, K. Y., van der Schaft, D. W. J., Post, M. J., and Baaijens, F. P. T. (2011). Advanced maturation by electrical stimulation: differences in response between $\mathrm{C} 2 \mathrm{C} 12$ and primary muscle progenitor cells. J. Tissue Eng. Regen. Med. 5, 529-539. doi: 10.1002/ term.345

Lanza, R., Langer, R., and Vacanti, J. P. (2011). Principles of Tissue Engineering. Academic Press. Available online at: https://market.android.com/details?id= book-rAFkm_4hOIMC (accessed September 02, 2018).
Lapin, M. R., Gonzalez, J. M., and Johnson, S. E. (2013). Substrate elasticity affects bovine satellite cell activation kinetics in vitro. J. Anim. Sci. 91, 2083-2090. doi: $10.2527 /$ jas.2012-5732

Lee, E. J., Malik, A., Pokharel, S., Ahmad, S., Mir, B. A., Cho, K. H., et al. (2014). Identification of genes differentially expressed in myogenin knock-down bovine muscle satellite cells during differentiation through RNA sequencing analysis. PLoS ONE 9:e92447. doi: 10.1371/journal.pone.0092447

Lee, S.-H., Gondro, C., van der Werf, J., Kim, N.-K., Lim, D.-J., Park, E.W., et al. (2010). Use of a bovine genome array to identify new biological pathways for beef marbling in Hanwoo (Korean Cattle). BMC Genomics 11:623. doi: 10.1186/1471-2164-11-623

Lehnert, S. A., Reverter, A., Byrne, K. A., Wang, Y., Nattrass, G. S., Hudson, N. J., et al. (2007). Gene expression studies of developing bovine longissimus muscle from two different beef cattle breeds. BMC Dev. Biol. 7:95. doi: 10.1186/1471-213X-7-95

Lehnert, S. A., Wang, Y. H., and Byrne, K. A. (2005). Development and application of a bovine cDNA microarray for expression profiling of muscle and adipose tissue. Aust. J. Exp. Agric. 44, 1127-1133. doi: 10.1071/EA03238

Lengi, A. J., and Corl, B. A. (2010). Factors influencing the differentiation of bovine preadipocytes in vitro. J. Anim. Sci. 88, 1999-2008. doi: 10.2527/jas.2009-2439

Lesman, A., Koffler, J., Atlas, R., Blinder, Y. J., and Kam, Z. (2011). Engineering vessel-like networks within multicellular fibrin-based constructs. Biomaterials. 32, 7856-7869. doi: 10.1016/j.biomaterials.2011.07.003

Levenberg, S., Rouwkema, J., Macdonald, M., Garfein, E. S., Kohane, D. S., Darland, D. C., et al. (2005). Engineering vascularized skeletal muscle tissue. Nat. Biotechnol. 23, 879-884. doi: 10.1038/nbt1109

Levy-Mishali, M., Zoldan, J., and Levenberg, S. (2009). Effect of scaffold stiffness on myoblast differentiation. Tissue Eng. Part A 15, 935-944. doi: 10.1089/ten.tea.2008.0111

Linde, D. A. (2018). Gene Expression Profiles in Longissimus Dorsi Muscle of Bonsmara and Nguni Cattle Fed Two Different Diets. Available online at: https:// repository.up.ac.za/handle/2263/65906

Listrat, A., Lebret, B., Louveau, I., Astruc, T., Bonnet, M., Lefaucheur, L., et al. (2016). How muscle structure and composition influence meat and flesh quality. Sci. World J. 2016:3182746. doi: 10.1155/2016/3182746

Liu, G., Liu, X., Shahzad, K., You, W., Loor, J. J., and Wan, F. (2018). Bioinformatics analyses of bovine adipose tissue transcriptome from lilu beef cattle at different stages of growth. PJZ 50:1855. doi: 10.17582/journal.pjz/2018.50.5.1847.1855

Liu, N., He, J. N., Yu, W. M., Liu, K. D., Cheng, M., Liu, J. F., et al. (2015). Transcriptome analysis of skeletal muscle at prenatal stages in polled dorset versus small-tailed han sheep. Genet. Mol. Res. 14, 1085-1095. doi: 10.4238/2015.February.6.12

Loh, Q. L., and Choong, C. (2013). Three-dimensional scaffolds for tissue engineering applications: role of porosity and pore size. Tissue Eng. Part B Rev. 19, 485-502. doi: 10.1089/ten.teb.2012.0437

Lovett, M., Lee, K., Edwards, A., and Kaplan, D. L. (2009). Vascularization strategies for tissue engineering. Tissue Eng. Part B Rev. 15, 353-370. doi: 10.1089/ten.teb.2009.0085

Luckett, C. R., Kuttappan, V. A., Johnson, L. G., Owens, C. M., and Seo, H.S. (2014). Comparison of three instrumental methods for predicting sensory texture attributes of poultry deli meat: texture of poultry deli meat. J. Sens. Stud. 29, 171-181. doi: 10.1111/joss. 12092

Lusk, J. L., and Norwood, F. B. (2011). Animal welfare economics. Applied Economic Perspectives. Available online at: https://academic.oup.com/aepp/ article-abstract/33/4/463/8220

Ma, Y. N., Wang, B., Wang, Z. X., Gomez, N. A., Zhu, M. J., and Du, M. (2018). Three-dimensional spheroid culture of adipose stromal vascular cells for studying adipogenesis in beef cattle. Animal 12, 1-7. doi: 10.1017/S1751731118000150

Mackey, A. L., Magnan, M., Chazaud, B., and Kjaer, M. (2017). Human skeletal muscle fibroblasts stimulate in vitro myogenesis and in vivo muscle regeneration. J. Physiol. 595, 5115-5127. doi: 10.1113/JP273997

Meadus, W., Duff, P., Juarez, M., Roberts, J., and Zantinge, J. (2018). Identification of marbling gene loci in commercial pigs in canadian herds. Collect. FAO Agric. 8:122. doi: 10.3390/agriculture8080122

Mehta, F., Theunissen, R., and Post, M. J. (2019). “Adipogenesis from Bovine Precursors," in Myogenesis: Methods and Protocols, ed. S. B. Rønning (New York, NY: Springer), 111-125. doi: 10.1007/978-1-4939-8897-6_8 
Mesa Ospina, N., Ospina Alvarez, S. P., Escobar Sierra, D. M., Rojas Vahos, D. F., Zapata Ocampo, P. A., and Ossa Orozco, C. P. (2015). Isolation of chitosan from Ganoderma lucidum mushroom for biomedical applications. J. Mater. Sci. Mater. Med. 26:135. doi: 10.1007/s10856-015-5461-Z

Miao, Z. G., Zhang, L. P., Fu, X., Yang, Q. Y., Zhu, M. J., Dodson, M. V., et al. (2016). Invited review: mesenchymal progenitor cells in intramuscular connective tissue development. Animal 10, 75-81. doi: 10.1017/S1751731115001834

Miller, M. F., Carr, M. A., Ramsey, C. B., Crockett, K. L., and Hoover, L. C. (2001). Consumer thresholds for establishing the value of beef tenderness. J. Anim. Sci. 79, 3062-3068. doi: 10.2527/2001.79123062x

Mitchell, A. D. (2007). Impact of research with cattle, pigs, and sheep on nutritional concepts: body composition and growth. J. Nutr. 137, 711-714. doi: $10.1093 /$ jn/137.3.711

Monte, D. F., Mem, A., Fernandes, M. R., Cerdeira, L., Esposito, F., Galvão, J. A., et al. (2017). Chicken meat as a reservoir of colistin-resistant Escherichia coli strains carrying mor-1 genes in South America. Antimicrob. Agents Chemother. 61: e02718-16. doi: 10.1128/AAC.02718-16

Moritz, M. S. M., Verbruggen, S. E. L., and Post, M. J. (2015). Alternatives for large-scale production of cultured beef: A review. J. Integr. Agric. 14, 208-216. doi: 10.1016/S2095-3119(14)60889-3

Moseti, D., Regassa, A., and Kim, W.-K. (2016). Molecular regulation of adipogenesis and potential anti-adipogenic bioactive molecules. Int. J. Mol. Sci. 17:124. doi: 10.3390/ijms17010124

Muroya, S., Nakajima, I., and Chikuni, K. (2001). Bovine skeletal muscle cells predominantly express a vascular cell adhesion molecule-1 seven-ig domain splice form. Zoolog. Sci. 18, 797-805. doi: 10.2108/zsj.18.797

Nekanti, U., Rao, V. B., Bahirvani, A. G., Jan, M., Totey, S., and Ta, M. (2010). Long-term expansion and pluripotent marker array analysis of Wharton's jelly-derived mesenchymal stem cells. Stem Cells Dev. 19, 117-130. doi: $10.1089 / \mathrm{scd} .2009 .0177$

Neubauer, M., Hacker, M., and Bauer-Kreisel, P. (2005). Adipose tissue engineering based on mesenchymal stem cells and basic fibroblast growth factor in Vitro. Tissue 11:1840-1851. doi: 10.1089/ten.2005.11.1840

Nguyen, N. T., Nguyen, H. M., Nguyen, C. V., Nguyen, T. V., Nguyen, M. T., Thai, H. Q., et al. (2016). Use of colistin and other critical antimicrobials on pig and chicken farms in southern vietnam and its association with resistance in commensal escherichia coli bacteria. Appl. Environ. Microbiol. 82, 3727-3735. doi: 10.1128/AEM.00337-16

Nicola, N. A., and Babon, J. J. (2015). Leukemia inhibitory factor (LIF). Cytokine Growth Factor Rev. 26, 533-544. doi: 10.1016/j.cytogfr.2015.07.001

Nollet, L. M. L. (ed.) (2012). Handbook of Meat, Poultry and Seafood Quality. Oxford, UK: Blackwell Publishing Ltd. doi: 10.1002/9781118352434

Oerther, S., Le Gall, H., Payan, E., Lapicque, F., Presle, N., Hubert, P., et al. (1999). Hyaluronate-alginate gel as a novel biomaterial: Mechanical properties and formation mechanism. Biotechnol. Bioeng. 63, 206-215.

Oguz, S., Tam, N., Aydogdu, A., Sumnu, G., and Sahin, S. (2018). Development of novel pea flour-based nanofibres by electrospinning method. Int. J. Food Sci. Technol. 53, 1269-1277. doi: 10.1111/ijfs.13707

Okamura, L. H., Cordero, P., Palomino, J., Parraguez, V. H., Torres, C. G., and Peralta, O. A. (2018). Myogenic differentiation potential of mesenchymal stem cells derived from fetal bovine bone marrow. Anim. Biotechnol. 29, 1-11. doi: 10.1080/10495398.2016.1276926

O'Neill, J. (2014). Antimicrobial resistance: tackling a crisis for the health and wealth of nations. Rev. Antimicrob. Resist 20, 1-16.

Oswald, J., Boxberger, S., Jørgensen, B., Feldmann, S., Ehninger, G., Bornhäuser, M., et al. (2004). Mesenchymal stem cells can be differentiated into endothelial cells in vitro. Stem Cells 22, 377-384. doi: 10.1634/stemcells.22-3-377

Pan, Y., Jing, J., Qiao, L., Liu, J., Zhao, J., An, L., et al. (2018). miR-124-3p affects the formation of intramuscular fat through alterations in branched chain amino acid consumption in sheep. Biochem. Biophys. Res. Commun. 495, 1769-1774. doi: 10.1016/j.bbrc.2017.12.046

Pandurangan, M., and Kim, D. H. (2015). A novel approach for in vitro meat production. Appl. Microbiol. Biotechnol. 99, 5391-5395. doi: $10.1007 /$ s00253-015-6671-5

Panskeep, J., and Others (2012). Low P. "Cambridge declaration of consciousness," in Frances Crick Memorial Conference on Consciousness in Human and nonHuman Animals at Churchill College, University of Cambridge (Cambridge).
Park, J. S., Chu, J. S., Tsou, A. D., Diop, R., Tang, Z., Wang, A., et al. (2011). The effect of matrix stiffness on the differentiation of mesenchymal stem cells in response to TGF- $\beta$. Biomaterials 32, 3921-3930. doi: 10.1016/j.biomaterials.2011.02.019

Passerieux, E., Rossignol, R., Chopard, A., Carnino, A., Marini, J. F., Letellier, T., et al. (2006). Structural organization of the perimysium in bovine skeletal muscle: junctional plates and associated intracellular subdomains. J. Struct. Biol. 154, 206-216. doi: 10.1016/j.jsb.2006.01.002

Patrick, C. W. Jr, Chauvin, P. B., Hobley, J., and Reece, G. P. (1999). Preadipocyte seeded PLGA scaffolds for adipose tissue engineering. Tissue Eng. 5, 139-151. doi: 10.1089/ten.1999.5.139

Pawlikowski, B., Vogler, T. O., Gadek, K., and Olwin, B. B. (2017). Regulation of skeletal muscle stem cells by fibroblast growth factors. Dev. Dyn. 246, 359-367. doi: $10.1002 /$ dvdy.24495

Pearson, A. M., and Dutson, T. R. (eds.) (1994). Quality Attributes and their Measurement in Meat, Poultry and Fish Products. Boston, MA: Springer.

Péault, B., Rudnicki, M., Torrente, Y., Cossu, G., Tremblay, J. P., Partridge, T., et al. (2007). Stem and progenitor cells in skeletal muscle development, maintenance, and therapy. Mol. Ther. 15, 867-877. doi: 10.1038/mt.sj.6300145

Pena, R. N., Quintanilla, R., Manunza, A., Gallardo, D., Casellas, J., and Amills, M. (2014). Application of the microarray technology to the transcriptional analysis of muscle phenotypes in pigs. Anim. Genet. 45, 311-321. doi: 10.1111/age.12146

Perry, L., Ben-Shaul, S., Landau, S., and Levenberg, S. (2017a). "CoCulture Systems for Vasculogenesis," in Vascularization for Tissue Engineering and Regenerative Medicine, eds. W. Holnthoner, A. Banfi, J. Kirkpatrick, and H. Redl (Cham: Springer International Publishing), 1-29. doi: 10.1007/978-3-319-21056-8_7-1

Perry, L., Flugelman, M. Y., and Levenberg, S. (2017b). Elderly patient-derived endothelial cells for vascularization of engineered muscle. Mol. Ther. 25, 935-948. doi: 10.1016/j.ymthe.2017.02.011

Peters, C. J., Wilkins, J. L., and Fick, G. W. (2007). Testing a complete-diet model for estimating the land resource requirements of food consumption and agricultural carrying capacity: The New York State example. Renew. Agric. Food Syst. 22, 145-153. doi: 10.1017/S1742170507001767

Picard, B., Berri, C., Lefaucheur, L., Molette, C., Sayd, T., and Terlouw, C. (2010). Skeletal muscle proteomics in livestock production. Brief. Funct. Genomics 9, 259-278. doi: 10.1093/bfgp/elq005

Picard, B., Cassar-Malek, I., Guillemin, N., and Bonnet, M. (2011). “4.32 - Quest for Novel Muscle Pathway Biomarkers by Proteomics in Beef Production," in Comprehensive Biotechnology (Second Edition), ed. M. Moo-Young (Burlington: Academic Press), 395-405. doi: 10.1016/B978-0-08-088504-9.00297-X

Picard, B., Lebret, B., Cassar-Malek, I., Liaubet, L., Berri, C., Le Bihan-Duval, E., et al. (2015). Recent advances in omic technologies for meat quality management. Meat Sci. 109, 18-26. doi: 10.1016/j.meatsci.2015.05.003

Poleti, M. D., Regitano, L. C. A., Souza, G. H. M. F., Cesar, A. S. M., Simas, R. C., Silva-Vignato, B., et al. (2018). Longissimus dorsi muscle label-free quantitative proteomic reveals biological mechanisms associated with intramuscular fat deposition. J. Proteomics 179, 30-41. doi: 10.1016/j.jprot.2018.02.028

Post, M., and van der Weele, C. (2014). "Chapter 78 - Principles of tissue engineering for food," in Principles of Tissue Engineering, Fourth Edition, eds R. Lanza, R. Langer, and J. Vacanti (Boston, MA: Academic Press), 1647-1662. doi: 10.1016/B978-0-12-398358-9.00078-1

Post, M. J. (2012). Cultured meat from stem cells: challenges and prospects. Meat Sci. 92, 297-301. doi: 10.1016/j.meatsci.2012.04.008

Post, M. J. (2014). Cultured beef: medical technology to produce food. J. Sci. Food Agric. 94, 1039-1041. doi: 10.1002/jsfa.6474

Post, M. J., and Hocquette, J.-F. (2017). "Chapter 16 - new sources of animal proteins: cultured Meat," in New Aspects of Meat Quality, ed. P. P. Purslow (Woodhead Publishing), 425-441. doi: 10.1016/B978-0-08-100593-4. 00017-5

Prieto, N., Roehe, R., Lavín, P., Batten, G., and Andrés, S. (2009). Application of near infrared reflectance spectroscopy to predict meat and meat products quality: a review. Meat Sci. 83, 175-186. doi: 10.1016/j.meatsci.2009. 04.016

Purslow, P. P. (2005). Intramuscular connective tissue and its role in meat quality. Meat Sci. 70, 435-447. doi: 10.1016/j.meatsci.2004.06.028

Purslow, P. P. (2010). Muscle fascia and force transmission. J. Bodyw. Mov. Ther. 14, 411-417. doi: 10.1016/j.jbmt.2010.01.005 
Purslow, P. P. (2014). New developments on the role of intramuscular connective tissue in meat toughness. Annu. Rev. Food Sci. Technol. 5, 133-153. doi: 10.1146/annurev-food-030212-182628

Qazi, T. H., Mooney, D. J., Pumberger, M., Geissler, S., and Duda, G. N. (2015). Biomaterials based strategies for skeletal muscle tissue engineering: existing technologies and future trends. Biomaterials 53, 502-521. doi: 10.1016/j.biomaterials.2015.02.110

Qiu, F., Xie, L., Ma, J.-E., Luo, W., Zhang, L., Chao, Z., et al. (2017). Lower Expression of SLC27A1 enhances intramuscular fat deposition in chicken via down-regulated fatty acid oxidation mediated by CPT1A. Front. Physiol. 8:449. doi: 10.3389/fphys.2017.00449

Rafii, S., Butler, J. M., and Ding, B.-S. (2016). Angiocrine functions of organ-specific endothelial cells. Nature 529, 316-325. doi: 10.1038/nature 17040

Ramírez-Espinosa, J. J., González-Dávalos, L., Shimada, A., Piña, E., VarelaEchavarria, A., and Mora, O. (2016). Bovine (Bos taurus) bone marrow mesenchymal cell differentiation to adipogenic and myogenic lineages. Cells Tissues Organs 201, 51-64. doi: 10.1159/000440878

Reardon, S. (2017). Resistance to last-ditch antibiotic has spread farther than anticipated. Nature News. Available online at: http://www.nature.com/news/ resistance-to-last-ditch-antibiotic-has-spread-farther-than-anticipated-1. 22140? (accessed July 17, 2018).

Redaelli, F., Sorbona, M., and Rossi, F. (2017). "10 - Synthesis and processing of hydrogels for medical applications," in Bioresorbable Polymers for Biomedical Applications, eds. G. Perale and J. Hilborn (Woodhead Publishing), 205-228. doi: 10.1016/B978-0-08-100262-9.00010-0

Reddy, N., and Yang, Y. (2011). Potential of plant proteins for medical applications. Trends Biotechnol. 29, 490-498. doi: 10.1016/j.tibtech.2011.05.003

Reilly, G. C., and Engler, A. J. (2010). Intrinsic extracellular matrix properties regulate stem cell differentiation. J. Biomech. 43, 55-62. doi: 10.1016/j.jbiomech.2009.09.009

Reverter, A., Hudson, N. J., Wang, Y., Tan, S.-H., Barris, W., Byrne, K. A., et al. (2006). A gene coexpression network for bovine skeletal muscle inferred from microarray data. Physiol. Genomics 28, 76-83. doi: 10.1152/physiolgenomics.00105.2006

Roberts, R. M., Yuan, Y., Genovese, N., and Ezashi, T. (2015). Livestock models for exploiting the promise of pluripotent stem cells. ILAR J. 56, 74-82. doi: 10.1093/ilar/ilv005

Rodriguez, B. L., and Larkin, L. M. (2018). "12 - Functional three-dimensional scaffolds for skeletal muscle tissue engineering," in Functional 3D Tissue Engineering Scaffolds, eds. Y. Deng and J. Kuiper (Woodhead Publishing), 279-304. doi: 10.1016/B978-0-08-100979-6.00012-4

Romao, J. M., Jin, W., Dodson, M. V., Hausman, G. J., Moore, S. S., and Guan, L. L. (2011). MicroRNA regulation in mammalian adipogenesis. Exp. Biol. Med. 236, 997-1004. doi: 10.1258/ebm.2011.011101

Rouwkema, J., and Khademhosseini, A. (2016). Vascularization and angiogenesis in tissue engineering: beyond creating static networks. Trends Biotechnol. 34, 733-745. doi: 10.1016/j.tibtech.2016.03.002

Rouwkema, J., Rivron, N. C., and van Blitterswijk, C. A. (2008). Vascularization in tissue engineering. Trends Biotechnol. 26, 434-441. doi: 10.1016/j.tibtech.2008.04.009

Rowlands, A. S., George, P. A., and Cooper-White, J. J. (2008). Directing osteogenic and myogenic differentiation of MSCs: interplay of stiffness and adhesive ligand presentation. Am. J. Physiol. Cell Physiol. 295, C1037-C1044. doi: 10.1152/ajpcell.67.2008

Rowley, J. A., and Mooney, D. J. (2002). Alginate type and RGD density control myoblast phenotype. J. Biomed. Mater. Res. 60, 217-223. doi: $10.1002 / \mathrm{jbm} .1287 . \mathrm{abs}$

Ruel-Gariépy, E., and Leroux, J.-C. (2004). In situ-forming hydrogels-review of temperature-sensitive systems. Eur. J. Pharm. Biopharm. 58, 409-426. doi: $10.1016 /$ j.ejpb.2004.03.019

Sack, M., Hofbauer, A., Fischer, R., and Stoger, E. (2015). The increasing value of plant-made proteins. Curr. Opin. Biotechnol. 32, 163-170. doi: $10.1016 /$ j.copbio. 2014.12 .008

Sadkowski, T., Ciecierska, A., Majewska, A., Oprzadek, J., Dasiewicz, K., Ollik, M., et al. (2014). Transcriptional background of beef marblingnovel genes implicated in intramuscular fat deposition. Meat Sci. 97, 32-41. doi: 10.1016/j.meatsci.2013.12.017
Sadkowski, T., Ciecierska, A., Oprzadek, J., and Balcerek, E. (2018). Breeddependent microRNA expression in the primary culture of skeletal muscle cells subjected to myogenic differentiation. BMC Genomics 19:109. doi: 10.1186/s12864-018-4492-5

Sarkar, N. S., and Choudhury, S. (2017). Algae as source of natural flavour enhancers - a mini review. Plant Sci. Today 4, 172-176. doi: 10.14719/pst.2017.4.4.338

Sarlio, S. (2018). Towards Healthy and Sustainable Diets: Perspectives and Policy to Promote the Health of People and the Planet. Springer. Available online at: https://books.google.co.in/books?id=upRNDwAAQBAJ\&redir_esc= y (accessed September 27, 2018).

Scarborough, P., Appleby, P. N., Mizdrak, A., and Briggs, A. D. M. (2014). Dietary greenhouse gas emissions of meat-eaters, fish-eaters, vegetarians and vegans in the UK. Climate Change. Available online at: https://link.springer.com/article/ 10.1007/s10584-014-1169-1\%EF\%BB\%BF (accessed September 13, 2018).

Schmidinger, K. (2012). Worldwide Alternatives to Animal Derived Foods-Overview and Evaluation Models: Solution to Global Problems Caused by Livestock.

Schneider, K. (2013). Concentrating on healthy feeding operations: the national school lunch program, cultured meat, and the path to a sustainable food future. J. Land Use Envtl. L. 29:145.

Schröder, M. J. A., and McEachern, M. G. (2004). Consumer value conflicts surrounding ethical food purchase decisions: a focus on animal welfare. Int. J. Consum. Stud. 28, 168-177. doi: 10.1111/j.1470-6431.2003. 00357. $\mathrm{x}$

Shahidi, F. (2002). "Lipid-derived flavors in meat products," in Meat Processing: Improving Quality, eds J. Kerry, J. Kerry and D. Ledward (Cambridge: Woodhead Publishing Ltd), 105-121. Available online at: https://books.google. co.in/books?id=_A-kAgAAQBAJ\&redir_esc=y (accessed September 03, 2018).

Shahidi, F. (2012). Flavor of Meat and Meat Products. Springer Science \& Business Media. Available online at: https://www.springer.com/gp/book/9781461359111 (accessed September 02, 2018).

Shahidi, F., Rubin, L. J., and D'Souza, L. A. (1986). Meat flavor volatiles: a review of the composition, techniques of analysis, and sensory evaluation. Crit. Rev. Food Sci. Nutr. 24, 141-243. doi: 10.1080/104083986095 27435

Shandalov, Y., Egozi, D., Freiman, A., Rosenfeld, D., and Levenberg, S. (2015). A method for constructing vascularized muscle flap. Methods 84, 70-75. doi: 10.1016/j.ymeth.2015.03.021

Shandalov, Y., Egozi, D., Koffler, J., Dado-Rosenfeld, D., Ben-Shimol, D., Freiman, A., et al. (2014). An engineered muscle flap for reconstruction of large soft tissue defects. Proc. Natl. Acad. Sci. U.S.A. 111, 6010-6015. doi: 10.1073/pnas.1402679111

Sharma, S., Thind, S. S., and Kaur, A. (2015). In vitro meat production system: why and how? J. Food Sci. Technol. 52, 7599-7607. doi: 10.1007/s13197-015$1972-3$

Shit, S. C., and Shah, P. M. (2014). Edible polymers: challenges and opportunities. J. Polym. Environ. 2014:427259. doi: 10.1155/2014/427259

Shoseyov, O., Posen, Y., and Grynspan, F. (2013). Human recombinant type I collagen produced in plants. Tissue Eng. Part A 19, 1527-1533. doi: $10.1089 /$ ten.tea.2012.0347

Shoseyov, O., and Stein, H. (2017). Collagen producing plants and methods of generating and using same. US Patent. Available online at: https://patents. google.com/patent/US9783816B2/en (accessed October 3, 2018).

Sims, D. E. (1986). The pericyte-A review. Tissue and Cell 18, 153-174. doi: 10.1016/0040-8166(86)90026-1

Slade, P. (2018). If you build it, will they eat it? Consumer preferences for plant-based and cultured meat burgers. Appetite 125, 428-437. doi: 10.1016/j.appet.2018.02.030

Smith, S. B., Kawachi, H., Choi, C. B., Choi, C. W., Wu, G., and Sawyer, J. E. (2009). Cellular regulation of bovine intramuscular adipose tissue development and composition. J. Anim. Sci. 87, E72-82. doi: 10.2527/jas.200 $8-1340$

Snell, K. D., Singh, V., and Brumbley, S. M. (2015). Production of novel biopolymers in plants: recent technological advances and future prospects. Curr. Opin. Biotechnol. 32, 68-75. doi: 10.1016/j.copbio.2014. 11.005

Specht, E. A., Welch, D. R., Rees Clayton, E. M., and Lagally, C. D. (2018). Opportunities for applying biomedical production and manufacturing 
methods to the development of the clean meat industry. Biochem. Eng. J. 132, 161-168. doi: 10.1016/j.bej.2018.01.015

Specht, L. (2019). An Analysis of Culture Medium Costs and Production Volumes for Cell-Based Meat. Available online at: https://www.gfi.org/files/sci-tech/cleanmeat-production-volume-and-medium-cost.pdf

Steinfeld, H., Gerber, P., Wassenaar, T., Castel, V., Rosales, M., Haan, C., et al. (2006). Livestock's Long Shadow: Environmental Issues and Options. Food and Agriculture Organization of the United Nations (FAO) Available online at: http://www.fao.org/3/a0701e/a0701e00.htm (accessed August 31, 2015).

Stephens, N., Di Silvio, L., Dunsford, I., Ellis, M., Glencross, A., and Sexton, A. (2018a). Bringing cultured meat to market: Technical, socio-political, and regulatory challenges in cellular agriculture. Trends Food Sci. Technol. 78, 155-166. doi: 10.1016/j.tifs.2018.04.010

Stephens, N., King, E., and Lyall, C. (2018b). Blood, meat, and upscaling tissue engineering: Promises, anticipated markets, and performativity in the biomedical and agri-food sectors. Biosocieties 13, 368-388. doi: 10.1057/s41292-017-0072-1

Sun, X., Li, M., Sun, Y., Cai, H., Lan, X., Huang, Y., et al. (2016). The developmental transcriptome sequencing of bovine skeletal muscle reveals a long noncoding RNA, lncMD, promotes muscle differentiation by sponging miR-125b. Biochim. Biophys. Acta 1863, 2835-2845. doi: 10.1016/j.bbamcr.2016.08.014

Sweeney, S. M., Orgel, J. P., Fertala, A., McAuliffe, J. D., Turner, K. R., Di Lullo, G. A., et al. (2008). Candidate cell and matrix interaction domains on the collagen fibril, the predominant protein of vertebrates. J. Biol. Chem. 283, 21187-21197. doi: 10.1074/jbc.M709319200

Syverud, B. C., Lee, J. D., VanDusen, K. W., and Larkin, L. M. (2014). Isolation and Purification of satellite cells for skeletal muscle tissue engineering. J. Regen. Med. Tissue Eng. 3:117. doi: 10.4172/2325-9620.1000117

Sze, J. H., Brownlie, J. C., and Love, C. A. (2016). Biotechnological production of hyaluronic acid: a mini review. Biotech 6:67. doi: 10.1007/s13205-016-0379-9

Takenouchi, T., Miyashita, N., Ozutsumi, K., Rose, M. T., and Aso, H. (2004). Role of caveolin-1 and cytoskeletal proteins, actin and vimentin, in adipogenesis of bovine intramuscular preadipocyte cells. Cell Biol. Int. 28, 615-623. doi: 10.1016/j.cellbi.2004.05.003

Tan, S. H., Reverter, A., Wang, Y., Byrne, K. A., McWilliam, S. M., and Lehnert, S. A. (2006). Gene expression profiling of bovine in vitro adipogenesis using a cDNA microarray. Funct. Integr. Genomics 6, 235-249. doi: 10.1007/s10142-005-0016-x

Tang, K. L., Caffrey, N. P., Nóbrega, D. B., Cork, S. C., Ronksley, P. E., Barkema, H. W., et al. (2017). Restricting the use of antibiotics in food-producing animals and its associations with antibiotic resistance in food-producing animals and human beings: a systematic review and meta-analysis. Lancet Planet Health 1, e316-e327. doi: 10.1016/S2542-5196(17)30141-9

Taniguchi, M., Guan, L. L., Zhang, B., Dodson, M. V., Okine, E., and Moore, S. S. (2008). Adipogenesis of bovine perimuscular preadipocytes. Biochem. Biophys. Res. Commun. 366, 54-59. doi: 10.1016/j.bbrc.2007.11.110

Tedesco, F. S., Moyle, L. A., and Perdiguero, E. (2017). "Muscle Interstitial Cells: A Brief Field Guide to Non-satellite Cell Populations in Skeletal Muscle," in Muscle Stem Cells: Methods and Protocols, eds. E. Perdiguero and D. D. W. Cornelison (New York, NY: Springer), 129-147. doi: 10.1007/978-1-4939-6771-1_7

Thornton, K. J., Kamange-Sollo, E., White, M. E., and Dayton, W. R. (2015). Role of G protein-coupled receptors (GPCR), matrix metalloproteinases 2 and 9 (MMP2 and MMP9), heparin-binding epidermal growth factor-like growth factor (hbEGF), epidermal growth factor receptor (EGFR), erbB2, and insulin-like growth factor 1 receptor (IGF-1R) in trenbolone acetatestimulated bovine satellite cell proliferation. J. Anim. Sci. 93, 4291-4301. doi: $10.2527 /$ jas.2015-9191

Thorsteinsdóttir, S., Deries, M., Cachaço, A. S., and Bajanca, F. (2011). The extracellular matrix dimension of skeletal muscle development. Dev. Biol. 354, 191-207. doi: 10.1016/j.ydbio.2011.03.015

Tizioto, P. C., Coutinho, L. L., Mourão, G. B., Gasparin, G., Malagó, W. Jr, Bressani, F. A., et al. (2016). Variation in myogenic differentiation 1 mRNA abundance is associated with beef tenderness in Nelore cattle. Anim. Genet. 47, 491-494. doi: 10.1111/age.12434

Tong, J., Zhu, M. J., Underwood, K. R., Hess, B. W., Ford, S. P., and Du, M. (2008). AMP-activated protein kinase and adipogenesis in sheep fetal skeletal muscle and 3T3-L1 cells. J. Anim. Sci. 86, 1296-1305. doi: 10.2527/jas.2007-0794
Trivedi, D. K., Hollywood, K. A., Rattray, N. J. W., Ward, H., Trivedi, D. K., Greenwood, J., et al. (2016). Meat, the metabolites: an integrated metabolite profiling and lipidomics approach for the detection of the adulteration of beef with pork. Analyst 141, 2155-2164. doi: 10.1039/C6AN00108D

Tse, J. R., and Engler, A. J. (2011). Stiffness gradients mimicking in vivo tissue variation regulate mesenchymal stem cell fate. PLoS ONE 6:e15978. doi: 10.1371/journal.pone.0015978

Tuomisto, H. L., and de Mattos, M. J. T. (2011). Environmental impacts of cultured meat production. Environ. Sci. Technol. 45, 6117-6123. doi: 10.1021/es200130u

United States Department of Agriculture (2018). Livestock, Poultry, \& Grain Market News. Available online at: https://www.ams.usda.gov/mnreports/ pywretailchicken.pdf (accessed September 12, 2018).

Van der Gucht, O. (2018). Cultured Meat: Current State of the Art and Future Challenges. Available online at: https://lib.ugent.be/fulltxt/RUG01/002/481/ 330/RUG01-002481330_2018_0001_AC.pdf

van der Weele, C., and Driessen, C. (2013). Emerging profiles for cultured meat; ethics through and as design. Animals 3, 647-662. doi: 10.3390/ani3030647

van Hinsbergh, V. W., Collen, A., and Koolwijk, P. (2001). Role of fibrin matrix in angiogenesis. Ann. N. Y. Acad. Sci. 936, 426-437. doi: 10.1111/j.1749-6632.2001.tb03526.x

Varzaneh, F. E., Shillabeer, G., Wong, K. L., and Lau, D. C. (1994). Extracellular matrix components secreted by microvascular endothelial cells stimulate preadipocyte differentiation in vitro. Metabolism 43, 906-912. doi: 10.1016/0026-0495(94)90275-5

Veiseth-Kent, E., de Almeida, A. M., Picard, B., and Hollung, K. (2018). "Proteomics in skeletal muscle research," in Proteomics in Domestic Animals: From Farm to Systems Biology, eds. A. M. de Almeida, D. Eckersall, and I. Miller (Cham: Springer International Publishing), 195-217. doi: 10.1007/978-3-319-69682-9_10

Veliça, P., and Bunce, C. M. (2011). A quick, simple and unbiased method to quantify C2C12 myogenic differentiation. Muscle Nerve 44, 366-370. doi: 10.1002/mus.22056

Verbeke, W., Marcu, A., Rutsaert, P., Gaspar, R., Seibt, B., Fletcher, D., et al. (2015). "Would you eat cultured meat?" Consumers' reactions and attitude formation in Belgium, Portugal and the United Kingdom. Meat Sci. 102, 49-58. doi: 10.1016/j.meatsci.2014.11.013

Verbeke, W. A. J., and Viaene, J. (2000). Ethical challenges for livestock production:meeting consumer concerns about meat safety and animalwelfare. J. Agric. Environ. Ethics 12, 141-151. doi: 10.1023/A:1009538613588

Verbruggen, S., Luining, D., van Essen, A., and Post, M. J. (2018). Bovine myoblast cell production in a microcarriers-based system. Cytotechnology 70, 503-512. doi: 10.1007/s10616-017-0101-8

Vitello, L., Radu, C., Malerba, A., Segat, D., Cantini, M., Carraro, U., et al. (2004). Enhancing myoblast proliferation by using myogenic factors: a promising approach for improving fiber regeneration in sport medicine and skeletal muscle diseases. Basic Appl. Myol. 14, 45-51.

Volz, A.-C., Huber, B., and Kluger, P. J. (2016). Adipose-derived stem cell differentiation as a basic tool for vascularized adipose tissue engineering. Differentiation 92, 52-64. doi: 10.1016/j.diff.2016.02.003

Von Heimburg, D., Serov, G., Oepen, T., and Pallua, N. (2003). Fat tissue engineering. Topics in Tissue Engineering. Available online at: http://www.oulu. fi/spareparts/ebook_topics_in_t_e/abstracts/heimburg_01.pdf.

von Tell, D., Armulik, A., and Betsholtz, C. (2006). Pericytes and vascular stability. Exp. Cell Res. 312, 623-629. doi: 10.1016/j.yexcr.2005.10.019

Wagner, W., Horn, P., Castoldi, M., Diehlmann, A., Bork, S., Saffrich, R., et al. (2008). Replicative senescence of mesenchymal stem cells: a continuous and organized process. PLOS ONE 3:e2213. doi: 10.1371/journal.pone. 0002213

Wang, G., Kim, W. K., Cline, M. A., and Gilbert, E. R. (2017a). Factors affecting adipose tissue development in chickens: a review. Poult. Sci. 96, 3687-3699. doi: $10.3382 / \mathrm{ps} / \mathrm{pex} 184$

Wang, T., Lew, J., Premkumar, J., Poh, C. L., and Naing, M. W. (2017b). Production of recombinant collagen: state of the art and challenges. Eng. Biol. 1, 18-23. doi: 10.1049/enb.2017.0003

Wang, Y.-H., Byrne, K. A., Reverter, A., Harper, G. S., Taniguchi, M., McWilliam, S. M., et al. (2005). Transcriptional profiling of skeletal muscle tissue from two breeds of cattle. Mamm. Genome 16, 201-210. doi: 10.1007/s00335-00 $4-2419-8$ 
Wang, Y. H., Bower, N. I., Reverter, A., Tan, S. H., De Jager, N., Wang, R., et al. (2009). Gene expression patterns during intramuscular fat development in cattle1. J. Ani. Sci. 87, 119-130. doi: 10.2527/jas.2008-1082

Wang, Y. M., Ding, X. B., Dai, Y., Liu, X. F., Guo, H., and Zhang, Y. (2015). Identification and bioinformatics analysis of miRNAs involved in bovine skeletal muscle satellite cell myogenic differentiation. Mol. Cell. Biochem. 404, 113-122. doi: 10.1007/s11010-015-2371-9

Warriss, P. D., and Rhodes, D. N. (1977). Haemoglobin concentrations in beef. J. Sci. Food Agric. 28, 931-934. doi: 10.1002/jsfa.2740281012

Webster, A. J. (2001). Farm animal welfare: the five freedoms and the free market. Vet. J. 161, 229-237. doi: 10.1053/tvjl.2000.0563

Webster, J. (2006). Animal sentience and animal welfare: What is it to them and what is it to us? Appl. Anim. Behav. Sci. 100, 1-3. doi: 10.1016/j.applanim.2006.05.012

Werkmeister, J. A., and Ramshaw, J. A. M. (2012). Recombinant protein scaffolds for tissue engineering. Biomed. Mater. 7:012002. doi: 10.1088/1748-6041/7/1/012002

Wickramasinghe, S., Cánovas, A., Rincón, G., and Medrano, J. F. (2014). RNASequencing: A tool to explore new frontiers in animal genetics. Livest. Sci. 166, 206-216. doi: 10.1016/j.livsci.2014.06.015

Wilfred, B. R., Wang, W.-X., and Nelson, P. T. (2007). Energizing miRNA research: a review of the role of miRNAs in lipid metabolism, with a prediction that miR103/107 regulates human metabolic pathways. Mol. Genet. Metab. 91, 209-217. doi: 10.1016/j.ymgme.2007.03.011

Will, K., Schering, L., Albrecht, E., Kalbe, C., and Maak, S. (2015). Differentiation of bovine satellite cell-derived myoblasts under different culture conditions. In Vitro Cell. Dev. Biol. Anim. 51, 885-889. doi: 10.1007/s11626-015-9916-9

Wittmann, K., Dietl, S., Ludwig, N., Berberich, O., Hoefner, C., Storck, K., et al. (2015). Engineering vascularized adipose tissue using the stromalvascular fraction and fibrin hydrogels. Tissue Eng. Part A 21, 1343-1353. doi: 10.1089/ten.tea.2014.0299

Woerdeman, D. L., Ye, P., Shenoy, S., Parnas, R. S., Wnek, G. E., and Trofimova, O. (2005). Electrospun fibers from wheat protein: investigation of the interplay between molecular structure and the fluid dynamics of the electrospinning process. Biomacromolecules 6, 707-712. doi: 10.1021/bm0494545

Wolf, M. T., Dearth, C. L., Sonnenberg, S. B., Loboa, E. G., and Badylak, S. F. (2015). Naturally derived and synthetic scaffolds for skeletal muscle reconstruction. Adv. Drug Deliv. Rev. 84, 208-221. doi: 10.1016/j.addr.2014.08.011

Won, S., Jung, J., Park, E., and Kim, H. (2018). Identification of genes related to intramuscular fat content of pigs using genome-wide association study. Asian-australas. J. Anim. Sci. 31, 157-162. doi: 10.5713/ajas.17.0218

Wood, J. D., Enser, M., Fisher, A. V., Nute, G. R., Sheard, P. R., Richardson, R. I., et al. (2008). Fat deposition, fatty acid composition and meat quality: a review. Meat Sci. 78, 343-358. doi: 10.1016/j.meatsci.2007.07.019

Wood, J. D., Richardson, R. I., Nute, G. R., Fisher, A. V., Campo, M. M., Kasapidou, E., et al. (2004). Effects of fatty acids on meat quality: a review. Meat Sci. 66, 21-32. doi: 10.1016/S0309-1740(03)00022-6

Woodard, S. L., Mayor, J. M., Bailey, M. R., Barker, D. K., Love, R. T., Lane, J. R., et al. (2003). Maize (Zea mays)-derived bovine trypsin: characterization of the first large-scale, commercial protein product from transgenic plants. Biotechnol. Appl. Biochem. 38, 123-130. doi: 10.1042/BA20030026

Xu, J., Towler, M., and Weathers, P. J. (2016). "Platforms for plant-based protein production," in Bioprocessing of Plant In Vitro Systems, eds. A. Pavlov and T. Bley (Cham: Springer International Publishing), 1-40. doi: 10.1007/978-3-319-32004-5_14-1
Yan, X., Zhu, M.-J., Dodson, M. V., and Du, M. (2013). Developmental programming of fetal skeletal muscle and adipose tissue development. $J$. Genomics 1, 29-38. doi: 10.7150/jgen.3930

Yang, S., Xin, X., Zlot, C., Ingle, G., Fuh, G., Li, B., et al. (2001). Vascular endothelial cell growth factor-driven endothelial tube formation is mediated by vascular endothelial cell growth factor receptor-2, a kinase insert domain-containing receptor. Arterioscler. Thromb. Vasc. Biol. 21, 1934-1940. doi: 10.1161/hq1201.099432

Yegappan, R., Selvaprithiviraj, V., Amirthalingam, S., and Jayakumar, R. (2018). Carrageenan based hydrogels for drug delivery, tissue engineering and wound healing. Carbohydr. Polym. 198, 385-400. doi: 10.1016/j.carbpol.2018. 06.086

Yin, H., Price, F., and Rudnicki, M. A. (2013). Satellite cells and the muscle stem cell niche. Physiol. Rev. 93, 23-67. doi: 10.1152/physrev.00043.2011

Young, D. A., Choi, Y. S., Engler, A. J., and Christman, K. L. (2013). Stimulation of adipogenesis of adult adipose-derived stem cells using substrates that mimic the stiffness of adipose tissue. Biomaterials 34, 8581-8588. doi: 10.1016/j.biomaterials.2013.07.103

Yuan, Y. (2018). Capturing bovine pluripotency. Proc. Natl. Acad. Sci. U. S. A. 115, 1962-1963. doi: 10.1073/pnas. 1800248115

Zahoor, I., de Koning, D.-J., and Hocking, P. M. (2017). Transcriptional profile of breast muscle in heat stressed layers is similar to that of broiler chickens at control temperature. Genet. Sel. Evol. 49:69. doi: 10.1186/s12711-017-0346-x

Zammit, P. S., Partridge, T. A., and Yablonka-Reuveni, Z. (2006). The skeletal muscle satellite cell: the stem cell that came in from the cold. J. Histochem. Cytochem. 54, 1177-1191. doi: 10.1369/jhc.6R6995.2006

Zeltinger, J., Sherwood, J. K., Graham, D. A., Müeller, R., and Griffith, L. G. (2001). Effect of pore size and void fraction on cellular adhesion, proliferation, and matrix deposition. Tissue Eng. 7, 557-572. doi: 10.1089/1076327017532 13183

Zhang, G. H., Lu, J. X., Chen, Y., Zhao, Y. Q., Guo, P. H., Yang, J. T., et al. (2014). Comparison of the adipogenesis in intramuscular and subcutaneous adipocytes from Bamei and Landrace pigs. Biochem. Cell Biol. 92, 259-267. doi: 10.1139/bcb-2014-0019

Zhang, W. R., Zhang, H. N., Wang, Y. M., Dai, Y., Liu, X. F., Li, X., et al. (2017). miR-143 regulates proliferation and differentiation of bovine skeletal muscle satellite cells by targeting IGFBP5. In Vitro Cell. Dev. Biol. Anim. 53, 265-271. doi: 10.1007/s11626-016-0109-y

Zhou, G., Wang, X., Yuan, C., Kang, D., Xu, X., Zhou, J., et al. (2017). Integrating miRNA and mRNA expression profiling uncovers miRNAs underlying fat deposition in sheep. Biomed Res. Int. 2017:1857580. doi: 10.1155/2017/ 1857580

Conflict of Interest Statement: SL is a co-founder and the CSO of Aleph Farms Ltd Israel.

The remaining author declares that the research was conducted in the absence of any commercial or financial relationships that could be construed as a potential conflict of interest.

Copyright $\odot 2019$ Ben-Arye and Levenberg. This is an open-access article distributed under the terms of the Creative Commons Attribution License (CC BY). The use, distribution or reproduction in other forums is permitted, provided the original author(s) and the copyright owner(s) are credited and that the original publication in this journal is cited, in accordance with accepted academic practice. No use, distribution or reproduction is permitted which does not comply with these terms. 